\title{
RANKING ORGANIZATIONAL RESILIENCE FACTORS IN ENTERPRISES USING A MODIFIED FUZZY ANALYTICAL HIERARCHY PROCESS
}

\author{
Danijela Tadic, ${ }^{*}$ Aleksandar Aleksic \\ Faculty of Engineering, University of Kragujevac, Kragujevac, Serbia
}

In the last few decades, the concept of organizational resilience has been developed, and in that manner, it represents an adequate management method for enterprises operating in the conditions of the economic crisis. In this paper, the problem of organizational resilience factors prioritization (ORF) is considered, which represents the first step in the determining of improvement strategies. The ORF ranking is set up as a task of a multi-criterion optimization inclusive of qualitative variables. Management teams at the level of every company assess the relative importance of each pair of business processes and the preference of the ORF within each business process using predefined linguistic expressions. The modeling of linguistic expressions is based on the theory of fuzzy sets. The aggregated values of the considered variables are obtained by applying the fuzzy ordered weighted averaging operator. The vector of a combined ORF priority was determined by using the fuzzy Analytic Hierarchy Process. The proposed model is illustrated by an illustrative example where the used data is obtained from the process of small and medium enterprises (SMEs) operating in central Serbia. It is shown that the developed model is very suitable for making decisions on changing business strategies in order to increase organizational resilience.

Keywords: organizational resilience factors, fuzzy set, fuzzy ordered weighted averaging operator (FOWA), fuzzy Analytic Hierarchy Process (FAHP)

JEL Classification: C61, D80, O21

\section{INTRODUCTION}

On the basis of good practice, it can be said that it is almost impossible to identify all the potential factors that may lead to the formation of one or more business risks (Spekman, 2004). Modern business has become very complex, this being caused by the development

\footnotetext{
* Correspondence to: D. Tadic, Faculty of Engineering, University of Kragujevac, Sestre Janjic 6, 34000 Kragujevac, Serbia; e-mail: galovic@kg.ac.rs
}

of new technologies, especially information and communication technologies (ICT). Complex and changeable market conditions are important risk factors that should be managed in the long term with an intention to ensure the sustainable development of an organization (Afgan et al, 2009). Identification, assessment and risk management in almost all organizations are based on the application of the ISO 31000:2008 risk management standard (principles and guidelines) as well as the BS 25999:2006 management and business continuity standard. Recently, the 
application of these standards has shown to be insufficient for managing risks successfully because organizations may be faced with very serious risks that may impede management to provide sustainable development.

The subject of the research presented in this paper can be defined as the identification and ranking of organizational resilience factors (ORF). These factors provide a clear market position of an organization, and the ORF rank provides an opportunity for each organization to learn from the experience of other similar organizations.

In this paper, the analyzed organizations belong to the group of the SME process industries. A process industry may be seen as a manufacturing industry using liquid raw materials for the production of finished goods, ensuring a continuous flow of process materials. It should also be noted that final products resulting from the processing industry cannot be broken down into raw materials from which they are made. Bearing in mind the continuity and interconnectedness of the process, it is important to improve the organizational resilience of this type of organizations.

Although there are a number of large multinational organizations in the field of process industries having sufficient resources to sustain the market, a large number of organizations in a process industry fit into the category of SMEs. The characteristics of SMEs can be expressed as follows (Article 2 of Annex Recommendation 2003/361/EC): the number of employees in SMEs is less than 250, the annual income of one SME is no bigger than EUR 50 million, and / or business assets in the balance sheet are less than or equal to EUR 43 million. It is clear that SMEs are recognized as an important economic sector for developing countries and for the developed countries tending to stimulate the entrepreneurial spirit leading to: (a) the creation of new jobs in the process industry, (b) the improvement of product quality (c) the development of a new research whose results should improve processes in the process industry, (d) the usage of advanced technologies (eco-innovation, green technologies etc.) and (e) the creation of new markets.
The aim of the research can be defined as prioritizing management initiatives in an exact way that should lead to the improvement of an organization's performance and its improved sustainability over time. Sustainable development of complex systems is achieved through a constant interaction of business processes and environments. As each organization operates in a highly variable environment, the management is expected to quickly adapt the organization to new business conditions or enable a high level of organizational resilience potential to successfully respond to the changes that have occurred.

This paper defines two basic hypotheses: (1) the level of organizational resilience of process SMEs can be calculated by $11 \mathrm{ORFs}$, (2) redefining strategies in order to improve the business performance of companies in a changing environment may be based on the obtained rank of ORFs.

Diverse management problems of enterprises such as the problem of organizational resilience management in SMEs discussed in this paper may be described by a number of different variables. The values of the control variables are based on decision-makers' estimations. Since the business environment is changing quickly and constantly, there is a realistic assumption that it is almost impossible to describe by the precise numbers of variable values. Describing the uncertain and imprecise values by using linguistic statements provided by decision-makers is close to the human way of thinking. In the literature, there are numerous mathematical theories which sufficiently well quantitatively describe linguistic expressions such as probability theory, fuzzy set theory or the theory of rough sets. Zimmermann (2001) considers applying the theory of fuzzy sets to be the most appropriate for the modeling of linguistic statements. In this paper, all the uncertainty and imprecision in the relative importance of business processes and the relative preference of the ORFs within each business process are described by the linguistic variables (Zadeh, 1975) and are modeled by the triangular fuzzy numbers (Klir \& Folger, 1988; Zimmeramnn, 2001).

The solution to the considered problem is obtained by using the extended fuzzy Analytic Hierarchy Process (FAHP). The rank of ORFs represents the input for 
the process of redefining the business improvement strategies of the discussed type of SMEs.

The paper is organized as follows: the literature review of the reference domain is shown in Section Two. Modelling uncertainty is described in Section Three. In Section Four, the extended fuzzy AHP method for ranking ORFs with respect to all business processes as well as their weight is displayed. In Section Five, an illustrative example illustrating the developed method is provided. In the illustrative example, the data obtained from the process industry SMEs existing in central Serbia is used. The conclusions are presented in Section Six.

\section{LITERATURE REVIEW}

Organizational resilience can be analyzed in different research fields, for example in the field of ecological systems (Folke, 2006) or in the domain of socio-economic systems (Adger, 2000). In the field of engineering, organizational resilience is defined as the ability to recognize and feel changes, disruptions and interruptions after which the system adapts and absorbs the same (Hollnagel et al, 2006). The mentioned differences did not allow the creation of a scientific consensus on the constituent elements of organizational resilience nor an appropriate methodology for its assessment.

Various factors (the development of new technologies, globalization etc.) have affected the increasing expectations of customers around the world. Regarding this, a company from the group of SMEs must be innovative and adapt to the emerged challenges (Lee et al, 2012). To achieve this, the SMEs management needs to combine old and new business models as well as enhance their own organizational resilience. This is a very important issue because the SME sector accounts for a significant part of the economic system in the EU states. Thus, for example in 2012, 99.8\% of enterprises were from the group of SMEs (Wymenga et al, 2012). This data indicates that SME sector gathers $67.4 \%$ of employees in the EU. The improvement of the organizational resilience of SMEs is determined by the market and the company's properties. Such organizations have a limited access to resources (Vossen, 1998), which makes them open and vulnerable to external entities, so their management have to define an appropriate strategy and provide resources to improve organizational resilience.

Resilience management can be achieved by applying an appropriate business strategy largely affecting the sustainability of SMEs and having a long-term impact on their business performance (Lengnick-Hall et al, 2011). If the effect of human resources within the organization is taken into account, the concept of organizational resilience should be implemented by leaders. Improvements in the field of human resources should result in improving organizational resilience.

In the process industry, organizational resilience is a relatively well-known concept in large and multinational organizations. One of the main challenges in the scope of organizational resilience is achieving the ability to conduct a continuous monitoring system, which includes the monitoring of specific ORFs in order to determine the limits and position the system (Vidal et al, 2009). In that manner, there are a large number of SMEs showing a need for a simple and reliable tool for assessing the capacity for recovery.

Organizational resilience may be treated as a fuzzy problem (Pendall et al, 2010) due to the fact that a large number of events affecting it may be described by uncertain and imprecise data (e.g. sudden disturbances or very slow changes). In order to make the measured values consistent over time, assessments should be made at the level of business processes. The factors contributing to organizational resilience could be estimated (Dinh et al, 2012), which gives a clear picture of the state of the process and their ability to recover if they face a disorder. There are a number of variable sizes which affect both the resilience of critical processes (Carvalho et al, 2008) and the total organizational resilience. Organizational resilience may be represented by appropriate models with certain variables modeled by fuzzy numbers (Chan, 2011). The main objective of this paper is to define a conceptual model for the evaluation of ORFs, which have the greatest impact on the organizational resilience of the considered SMEs. 
The evaluation and ranking of ORFs in the presence of uncertainty in the process industry SMEs can be set up as a task of a multi-criteria optimization (MCO). One of the MCO methods, commonly used for solving management problems in a variety of research fields, is the fuzzy Analytic Hierarchy Process (FAHP) (Weeck et al, 1997), which is an extension of conventional AHP (Saaty, 1990). FAHP allows a holistic way in the management modeling problems, and that is the main difference between the FAHP and the other MCO methods.

In the literature, there are numerous approaches to handling the FAHP. One of the most common approaches for the treatment of the FAHP with triangular fuzzy numbers is developed by Chang (1996). The usage of this approach does not require complex mathematical calculations and has the ability to sufficiently support the human way of thinking. This approach can easily be implemented in the conventional AHP (Kwong \& Bai, 2003). The weight vector of business processes and the priorities vectors of the ORFs within each business process are obtained by using a method for comparing the fuzzy numbers (Dubois \& Prade, 1980; Bass \& Kwakeernak, 1977). The priorities of the ORFs with respect to all business processes and their weights are calculated as in the conventional AHP.

In a number of papers dealing with different management problems, solutions are found using the FAHP (Chang, 1996). The paper (Xi \& Qin, 2013) treats the problem of an overall assessment of each product's quality. Priopriteta The priority determination of organizational performance indicators are considered in T. F. Bozbura and A. Beskese (2007). The ranking of the key influence factors of E-business is discussed in F. Kong and H. Liu (2005). In many papers where the solution is sought by using two or more methods of the MCO, the FAHP is used to find the weight of the considered size (Torfi et al, 2010, Tadic et al, 2013).

Respecting the good characteristic of the FAHP, the authors of this study believe that the evaluation and ranking of the ORFs may be well-conducted by the application of the extended FAHP.

\section{MODELLING OF UNCERTAINTIES}

In this paper, the linguistic expressions are modeled by using the fuzzy sets theory. The fuzzy set is represented by its membership function which the parameters are shaped for, and the location on the universe of discourse. The membership function shape of a fuzzy set can be obtained based on one's experience, the subjective belief of decision makers, intuition and the contextual knowledge of the concept modelled (Zimmermann, 2001). In the literature, triangular and trapezoidal fuzzy numbers are commonly used for the modeling of different types of uncertainties. Using these fuzzy numbers does not require complex mathematical calculations, and the accuracy of the results is quite appropriate. According to some authors, using fuzzy sets of higher types and levels has not as yet played a significant role in real applications of the fuzzy sets theory (Klir and Yuan, 1995). The domain of fuzzy sets can be defined on different measurement scales: for instance, a common measurement scale (by analogy to the conventional $\mathrm{AHP})$, measurement scales defined in real line into intervals [0-1] and [1-5].

\section{The basic definitions of the fuzzy sets theory}

The basic definitions of the fuzzy sets theory are presented according to (Dubois \& Prade, 1980; Klir \& Folger, 1988; Zimmermann, 2001).

Definition 1. Uncertainty can be defined as a lack of relevant information on which a decision maker can qualitatively and quantitatively describe a variable (Zimmermann, 2001).

Definition 2. A linguistic variable is a variable whose values are expressed in linguistic terms (Zadeh, 1975).

Definition 3. Fuzzy set $\tilde{A}$ is defined as a set of organized pairs:

$\tilde{A}=\left\{x, \mu_{\tilde{A}}(x) \mid x \in X, 0 \leq \mu_{\tilde{A}}(x) \leq 1\right\}$

where:

Fuzzy set $\tilde{A}$ is defined on the universe set $X \in R$. In general, set $X$ can be either finite or infinite. $\mu_{\tilde{A}}(x)$ is a membership function of fuzzy set $\tilde{A}$. Each fuzzy set is completely and uniquely determined by its membership function. 
Definition 4. Fuzzy number $\tilde{A}$ is a convex normalized fuzzy set $\tilde{A}$ of the real line $\mathrm{R}$ such that: if exist $\mathrm{X}_{0} \in \mathrm{R}$ such that $\mu_{\widetilde{A}}\left(x_{0}\right)=1 \mu_{\tilde{A}}(x)$ is piecewise continuous.

Definition 5. Fuzzy number $\tilde{A}$ on $\mathrm{R}$ is to be a triangular fuzzy number if its membership function

$\mu_{\tilde{A}}(x) R \rightarrow[0,1]$ is equal to

$\mu_{\tilde{A}}(x)=\left\{\begin{array}{cc}\frac{x-a}{m-a} & x \in[a, m] \\ \frac{d-x}{d-m} & x \in[m, d] \\ 0 & \text { ostalo }\end{array}\right\}$.

Definition 6. A matrix $\tilde{M}$ is called a fuzzy matrix if at least one element in $\tilde{M}$ is a fuzzy number (Bortolan and Degani, 1985).

Definition 7. The operations of fuzzy numbers are based on the theorem set by Dubois and Prade (1980).

Let two fuzzy numbers $\tilde{A}=\left\{x, \mu_{\tilde{A}}(x) \mid x \in R\right\}$ and $\tilde{B}=\left\{y, \mu_{\tilde{B}}(y) \mid y \in R\right\}$.

The membership functions of these fuzzy numbers are monotonous and subjective from zero to one and ${ }^{*}$ is a continuous binary operation. Then $\tilde{A}^{*} \tilde{B}$ is a fuzzy number denoted such as $\tilde{C}=\tilde{A}^{*} \tilde{B}$. Values in the domain of fuzzy number $\tilde{C}$, can be calculated as $\mathrm{z}=\mathrm{x}^{*} \mathrm{y}$ and $\mu_{\tilde{C}}(z)=\operatorname{supmin}_{z=x^{*} y}\left(\mu_{\tilde{A}}(x), \mu_{\tilde{B}}(y)\right)$

Consider two triangular fuzzy numbers

$\tilde{A}=\left(l_{1}, m_{1}, u_{1}\right)$ and $\tilde{B}=\left(l_{2}, m_{2}, u_{2}\right)$.

Their operational laws are as follows:

1. $\left(l_{1}, m_{1}, u_{1}\right)+\left(l_{2}, m_{2}, u_{2}\right)=\left(l_{1}+l_{2}, m_{1}+m_{2}, u_{1}+u_{2}\right)$

2. $\left(l_{1}, m_{1}, u_{1}\right)-\left(l_{2}, m_{2}, u_{2}\right)=\left(l_{1}-u_{2}, m_{1}-m_{2}, u_{1}-l_{2}\right)$

3. $\left(l_{1}, m_{1}, u_{1}\right):\left(l_{2}, m_{2}, u_{2}\right)=\left(l_{1}: u_{2}, m_{1}: m_{2}, u_{1}: l_{2}\right)$

4. $\lambda \cdot\left(l_{1}, m_{1}, u_{1}\right)=\left(\lambda \cdot l_{1}, \lambda \cdot m_{1}, \lambda \cdot u_{1}\right)$

5. $\left(l_{1}, m_{1}, u_{1}\right)^{-1}=\left(\frac{1}{u_{1}}, \frac{1}{m_{1}}, \frac{1}{l_{1}}\right)$

Definition 8. Arithmetic defuzzification means extracting a single scalar value from a fuzzy set which most appropriately represents the fuzzy set. The moment rule is the most often applied defuzzification technique. It takes as a representative scalar the projection of the central area under the membership function curve to the x-axis.

The modeling of the relative importance of business processes and the relative preference of organizational resilience factors

It can be assumed that all the business processes and the organizational resilience factors (ORF) for the considered business processes are not usually of the same relative importance. Also, they can be considered as unchangeable during the considered period of time. The relative importance of the business processes and the relative preference of the ORF under each business process are provided by SMEs' decision makers. Decision makers' judgements are based on their knowledge, experience, results of good practice, defined corporate strategies etc.

In this paper, the relative importance of business processes and the relative preference of the ORF are stated by pair-wise comparison matrices (by analogy to AHP). We think that the judgment of each pair of the treated variables best suits human-decision nature instead of a direct access to the assessment. In the conventional AHP, the measurement scale is defined on real sets into interval [1-9]. The use of the discrete scale of the AHP is simple and easy but not sufficient to take into account uncertainty associated with the mapping of one's perception to a number (Kwong and Bai, 2003). It is realistic to introduce the assumption that decision makers better express their opinions by linguistic expressions.

The elements of these matrices are linguistic expressions modeled by triangular fuzzy numbers

$W_{p p^{\prime}}^{e}=\left(x ; l_{p p^{\prime}}^{e}, m_{p p^{\prime}}^{e}, u_{p p^{\prime}}^{e}\right)$,

$W_{i i^{\prime}}^{p e}=\left(x ; l_{i i^{\prime}}^{p e}, m_{i i^{\prime}}^{p e}, u_{i i^{\prime}}^{p e}\right)$ respectively,

$p, p^{\prime}=1, . ., P ; p \neq p^{\prime} ; i, i^{\prime}=1, . ., I ; i \neq i^{\prime} ; e=1, . ., E$

The lower and upper bounds of the used triangular fuzzy numbers are denoted as $l_{p p^{\prime}}^{e}, l_{i i^{\prime}}^{p e}, u_{p p^{\prime}}^{e}, u_{i i^{\prime}}^{p e}$ and modal values $m_{p p^{\prime}}^{e}, m_{i i}^{p e}$ which belong to interval [1-5]. 
Value 1 denotes that the relative importance of business processes $\mathrm{p}$ and the relative preference ORF organizational resilience factor i compared to business process $p^{\prime}$, as well as ORF $i$ ' is equal. Value 5 denotes that business process $p_{i}$, as well as OFR $i$ is extremely more important than business process $p^{\prime}$ as well as ORF , i', respectively.

If the strong relative importance of business process $p$ ' over business process $p$ holds, then a pairwise comparison scale can be represented by fuzzy number

$$
\tilde{W}_{p p^{\prime}}^{e}=\left(\tilde{W}_{p p^{\prime}}^{e}\right)^{-1}=\left(\frac{1}{u_{p p^{\prime}}^{e}}, \frac{1}{m_{p p^{\prime}}^{e}}, \frac{1}{l_{p p^{\prime}}^{e}}\right) \text {. }
$$

In similar way, it may be presented:

$$
\begin{aligned}
& \tilde{W}_{i i^{\prime}}^{p e}=\left(\tilde{W}_{i i^{\prime}}^{p e}\right)^{-1}=\left(\frac{1}{u_{i i^{\prime}}^{p e}}, \frac{1}{m_{i i^{\prime}}^{p e}}, \frac{1}{l_{i i^{\prime}}^{p e}}\right), p, p^{\prime}= \\
& =1, \ldots, P ; p \neq p^{\prime} ; i, i^{\prime}=1, \ldots, I ; i \neq i^{\prime} ; e=1, \ldots, E .
\end{aligned}
$$

If $p=p^{\prime} ; i=i^{\prime}\left(i, i^{\prime}=1, \ldots, I ; p, p^{\prime}=1, \ldots, P\right)$, then the relative importance of business processes and the relative preference of ORF $i$ ' under business process $p$, is represented by a single point 1 , which is a triangular fuzzy number $(1,1,1)$.

In this paper, the management team uses five linguistic expressions modeled by triangular fuzzy numbers given in the following way:

very low importance /preference - $\tilde{R}_{1}=(1,1,2)$

low importance/preference $-\tilde{R}_{2}=(1,2,3)$

medium importance/preference $-\tilde{R}_{3}=(1,3,5)$

high importance/preference - $\tilde{R}_{4}=(3,4,5)$

very high importance/preference $-\tilde{R}_{5}=(4,5,5)$

\section{METHODOLOGY}

The concept of an extent analysis is presented in (Chang, 1996). By using this concept, the relative importance of business processes, the relative priorities of ORFs under each business process, and the composite priorities ORFs are calculated. The concept of an extent analysis is presented.

\section{Mathematical problem statement}

In this paper, we consider numerous processing SMEs. Formally, these SMEs are presented by set $E=\{1, \ldots, e, \ldots, E\}$. The index for an SME is denoted as $\mathrm{e}$, and $\mathrm{E}$ is the total number of the considered SMEs. The management team of each SME consists of: the owner, a production manager, and a financial manager. It can be assumed that the management team at the SME level make decisions by consensus. All the considered SMEs are grouped into $G$ different groups which can formally be presented as $G=\{1, \ldots, g, \ldots, G\}$. The index for an SMEs group is denoted as $g$, $\mathrm{g}=1, . ., \mathrm{G}$. In this paper, the SMEs are grouped by using the $A B C$ classification method based on Pareto analyses. The SMEs are divided into three groups: A, B, and C, according to the realized annual profit. Typically, the A-class SMEs account for about 5-10\% of the number of the considered SMEs, and the management teams of these SMEs receive the highest importance of the assessment. The B-class SMEs account for about 15 percent in terms of the number of the treated SMEs. The management teams of these SMEs have medium importance for the assessment of the production process quality. All the other SMEs belong to Class $\mathrm{C}$, which accounts for about 80 percent of the total number of THE considered SMEs and only about 5 percent of the SMEs' annual profit value. The management teams of this group of SMEs have low importance for the assessment of the considered problem. The importance of each group of management teams $w_{g}, g=1, . ., G$ is determined based on the results of good practice in the SME processing industry. Also, it can be mentioned that decision makers under the management team are equally important.

Formally, the business processes of the considered SMEs are presented by set $P=\{1, \ldots, p, \ldots, P\}$. The total number of business processes is $\mathrm{P}$, and $\mathrm{p}$ is an index for a business process. The ORFs are presented by set $I=\{1, \ldots ., i, . ., I\}$. The index for ORF is denoted as $\mathrm{i}$, and I is the total number of the identified OFRs. The fuzzy ratings of the relative importance of the business processes and the relative preference of the ORFs under each business process are given by each member of the management team at the SME 
level. These fuzzy ratings are modelled by triangular fuzzy numbers

$\tilde{W}_{p p^{\prime}}^{e}=\left(x ; l_{p p^{\prime}}^{e}, m_{p p^{\prime}}^{e}, u_{p p^{\prime}}^{e}\right)$

$\tilde{W}_{i i^{\prime}}^{p e}=\left(x ; l_{i i}^{p e}, m_{i i}^{p e}, u_{i i^{\prime}}^{p e}\right)$

$p, p^{\prime}=1, . ., P ; p \neq p^{\prime} ; i, i^{\prime}=1, . ., I ; i \neq i^{\prime} ; e=1, . ., E$.

Since the decision makers belonging to the management team of each SME have the same importance, the relative importance of the business processes and the relative preference of ORFs under each business process are determined by the average value method. These values are modelled by triangular fuzzy numbers according to the fuzzy algebra rules (Klir \& Folger, 1988; Zimmermann, 2001). As mentioned, the management teams have unequal importance, so the aggregated values of the relative importance of the business processes, and the aggregated values of the relative preference ORFs, are calculated by using the fuzzy ordered weighted averaging operator (FOWA) explained in (Merigó \& Casanovas 2008). These values are denoted as:

$\tilde{w}_{p p^{\prime}}=\left(x ; l_{p p^{\prime}}, m_{p p^{\prime}}, u_{p p^{\prime}}\right), \tilde{w}_{i i^{\prime}}^{p}=\left(x ; l_{i i^{\prime}}^{p}, m_{i i^{\prime}}^{p}, u_{i i^{\prime}}^{p}\right)$

$p, p^{\prime}=1, . ., P ; p \neq p^{\prime} ; i, i^{\prime}=1, . ., I ; i \neq i^{\prime}$.

By using the FAHP (Chang, 1996) weights vector of the identified business processes,

$V_{p}=\left[w_{p}\right]_{1 x P}, p=1, . ., P$

and the weights vector of the ORFs under each business process, $V_{i p}=\left[w_{i p}\right]_{1 X I} ; i=1, \ldots, I ; p=1, ., P$ are given. The value of the combined priority index $r_{i}$, $i=1, \ldots, I$ is associated to each ORF and based on that, the ORH ranking is done. The ORF associated with the largest or the smallest value is ranked in the first place, or the last. The first-place rank located ORF has the biggest impact on the organizational resilience of the considered SMEs. In other words, on the basis of the ORF's obtained rank, the priority of management initiatives that should lead to an organizational resilience enhancement in SMEs is determined.

\section{The Algorithm of the extended FAHP}

The problem of the evaluation and ranking of the ORFs in processing SMEs by a modified FAHP is shown.

Step 1. The considered problem is decomposed into several less complex management problems. The fuzzy pair-wise comparison matrix of the relative importance of the business processes,

$\tilde{W}_{p}^{e}=\left[\tilde{W}_{p p^{\prime}}^{e}\right]_{P X P}, p=1, . ., p ; e=1, \ldots, E$

and the fuzzy matrix of the priorities of the ORFs with respect to each treated business process,

$$
\tilde{W}_{i}^{p e}=\left[\tilde{W}_{i i}^{p e}\right]_{I x I}, i=1, . ., I ; p=1, . ., p ; e=1, \ldots, E
$$

are constructed.

Step 2. Calculate the aggregated values of the elements of the constructed pair-wise comparison matrices for each group of SMEs:

$\tilde{W}_{p p^{\prime}}^{g}=\frac{1}{E_{g}} \cdot \sum_{e=1}^{E_{g}} \tilde{W}_{p p^{\prime}}^{e}, \tilde{W}_{i i^{\prime}}^{p g}=\frac{1}{E_{g}} \cdot \sum_{e=1}^{E_{g}} \tilde{W}_{i i^{\prime}}^{p e}$,

$p=1, . ., P ; i=1, . ., I ; e=1, . ., E_{g}$

where $E_{g}, g=1, \ldots, G$ is the total number of the management teams of the g-group SMEs.

Step 3. Calculate the aggregated relative importance of the business processes and the ORFs under each business process by using the FOWA:

$$
\begin{aligned}
& \tilde{w}_{p p^{\prime}}=\operatorname{FOWA}\left(\tilde{W}_{p p^{\prime}}^{g}\right)=\sum_{g=1}^{3} w_{g} \cdot \tilde{W}_{p p^{\prime}}^{g}, \\
& \tilde{w}_{i i^{\prime}}^{p}=\operatorname{FOWA}\left(\tilde{W}_{i i^{\prime}}^{p g}\right)=\sum_{g=1}^{3} w_{g} \cdot \tilde{W}_{i i^{\prime}}^{p g}, \\
& p=1, . ., P ; i=1, \ldots, I ; g=1,2,3
\end{aligned}
$$

Step 4. Determine the pair-wise comparison matrix of the relative importance of the business processes, $W_{p}=\left[w_{p p^{\prime}}\right]_{P \times P}, p=1, . ., P$

and the pair-wise comparison matrix of the relative preference of the OPFs under each business process, $W_{i}^{p}=\left[w_{i i}^{p}\right]_{I x I}, p=1, . ., P ; i=1, . ., I \quad$ such that: 
$\tilde{w}_{p p^{\prime}}=\operatorname{defuzz}\left(\tilde{w}_{p p^{\prime}}\right), w_{i i^{\prime}}^{p}=\operatorname{defuzz}\left(\tilde{w}_{i i^{\prime}}^{p}\right)$,

$i=1, . ., I ; p=1, . ., P$

The representative scalars of the triangular fuzzy numbers are given by using the moment method (Klir and Folger, 1988).

Step 5. The consistency of the fuzzy pair-wise comparison matrices $W_{p}=\left[w_{p p^{\prime}}\right]_{P X P}$ and $W_{i}^{p}$, $p=1, . ., P ; i=1, . ., I$ should be checked. A necessary condition for consistency is that these matrices be reciprocal. A sufficient condition for consistency is that the principal eigenvalue of each matrix, $\lambda_{\max }$ be equal to dimension of matrix (Saaty, 1990). The eigenvector method also yields a natural measure for inconsistency. The consistency index (C.I.) of matrices $W_{p}$ and $W_{i}{ }^{p}$, $p=1, . ., P ; i=1, . ., I$ can be calculated as:

\section{C.I.=C.R./R.I.}

where:

$$
C . R .=\frac{\lambda_{\max }^{p}-P}{P-1}, C . R .=\frac{\lambda_{\max }^{i p}-I}{I-1}
$$

and an eigenvectors of matrices $W_{p}$ and $W_{i}^{p}, p=1, . ., P$; $i=1, . ., I$ are denoted as $\lambda_{\max }^{p}$, and $\lambda_{\max }^{i p}$, respectively.

The eigenvalues of vectors can be calculated:

$W_{p}^{\text {nor }} \cdot \lambda_{\max }^{p}=\lambda_{\max }^{p} \cdot\left(w_{p}\right)^{\prime},\left(W_{i}^{p}\right)^{\text {nor }} \cdot \lambda_{\max }^{p}=$

$=\lambda_{\max }^{i p} \cdot\left(w_{i p}\right)^{\prime}$

The elements of matrices $W_{p}^{\text {nor }} i\left(W_{i}^{p}\right)^{\text {nor }}, i=1, . ., I$; $p=1, . ., P$ are calculated by using a linear normalization procedure for benefit-type variables (Hwang \& Yoon, 1981).

A random index (R.I.) is defined for each size of matrix as presented in Table 1 (Vargas, 1982).
The number $10 \%$ is the accepted upper limit for C.I. If C.I. > 0.1, it is recommended that the management team should revise some assessments since they are highly inconsistent. The method for choosing ehich assessments which should be considered for revision in order to reduce inconsistency is proposed in (Harkar, 1987).

Step 6. The vector weights of the identified business processes, $V_{p}=\left[w_{p}\right]_{1 \times P}, p=1, . ., P$ and the vector preference of the ORFs under each business process, $V_{i p}=\left[w_{i p}\right]_{1 x I} ; i=1, \ldots, I ; p=1, . ., P$ are calculated by using the concept of an extent analysis (Chang, 1996).

Let $X=\left\{x_{1}, \ldots, x_{i}, \ldots, x_{P}\right\}$ be an object set, and $Y=\left\{y_{1}, \ldots, y_{j}, \ldots, y_{P}\right\}$ be a goal set. According to the concept of the extent analysis (Chang, 1996), each object is taken and the extent analysis for each goal is performed, respectively. Therefore, the $\mathrm{P}$ extent analysis values for each object are marked by the following signs:

$N_{i}^{1},{ }_{i} N_{i}^{j}, \ldots, N_{i}^{P}, i=1, . ., P$, where $N_{i}^{j}, j=1, . ., P$ are triangular fuzzy numbers.

The value of the fuzzy synthetic extent with respect to the i-th object is defined as:

$\tilde{S}_{i}=\sum_{j=1}^{P} N_{i}^{j} \cdot\left[\sum_{i=1}^{P} \sum_{j=1}^{P} N_{i}^{j}\right]^{-1}$

where:

$\sum_{j=1}^{P} N_{i}^{j}=\left(\sum_{p^{\prime}=1}^{P} l_{p p^{\prime}}, \sum_{p^{\prime}=1}^{P} m_{p p^{\prime}}, \sum_{p^{\prime}=1}^{P} u_{p p^{\prime}}\right)$

$\sum_{i=1}^{P} \sum_{j=1}^{P} N_{i}^{j}=\left(\sum_{p=1}^{P} \sum_{p^{\prime}=1}^{P} l_{p p^{\prime}}, \sum_{p=1}^{P} \sum_{p^{\prime}=1}^{P} m_{p p^{\prime}}, \sum_{p=1}^{P} \sum_{p^{\prime}=1}^{P} u_{p p^{\prime}}\right)$

Table 1 Random index (RI)

\begin{tabular}{lcccccccccccc}
\hline Size of matrix & 3 & 4 & 5 & 6 & 7 & 8 & 9 & 10 & 11 & 12 & 13 & 14 \\
R.I. & 0.58 & 0.90 & 1.12 & 1.24 & 1.32 & 1.41 & 1.45 & 1.49 & 1.51 & 1.48 & 1.56 & 1.57 \\
\hline
\end{tabular}

Source: Vargas, 1982 
The weights vector of the identified business processes is represented as:

$$
\left(\left(\operatorname{Bel}\left(\tilde{S}_{1}\right)\right), \ldots,\left(\operatorname{Bel}\left(\tilde{S}_{i}\right)\right), \ldots,\left(\operatorname{Bel}\left(\tilde{S}_{P}\right)\right)\right)
$$

Where $\operatorname{Bel}\left(\tilde{S}_{i}\right)$ is the measure of the belief according to which triangular fuzzy number $\tilde{S}_{i}$ is bigger than all other triangular fuzzy numbers $\tilde{S}_{i}^{\prime}, \quad\left(i, i^{\prime}=1, . ., P\right.$; $\left.i \neq i^{\prime}\right)$. This value is obtained by applying the method for fuzzy numbers comparison (Dubois \& Prade, 1980; Bass \& Kwakernaak, 1977) (see Appendix).

After normalizing, the normalized weights vector of the identified business processes $V_{p}$ is obtained:

$V_{p}=\left(w_{1}, \ldots, w_{p}, \ldots, w_{P}\right)$

$w_{p}$ is a non-fuzzy number, which gives the priority to the weights of one business process over the other.

In a similar way, the normalized preference vector of the ORFs under each business process is obtained.

Step 7. Calculate to composite priorities for each ORF, $r_{i}, \mathrm{i}=1, \ldots \mathrm{I}$ :

$r_{i}=\sum_{p=1}^{P} w_{p} \cdot w_{i}^{p}, i=1, . ., I ; p=1, . ., P$.

Step 8. Rank all $r_{i}, \mathrm{i}=1, \ldots \mathrm{I}$ in the decreasing order.

\section{ILLUSTRATIVE EXAMPLE}

The improvement of organizational resilience is a very important issue for the management teams of the process industry SMEs in developing countries. The proposed method is illustrated with the real data obtained in the 53 process industry SMEs operating in central Serbia. The considered SMEs are certified according to the requirements of the ISO 9001, necessary for defining the reference model of organization. As the ranking of organizational resilience factors is done at the level of business processes, it is important to define the business processes in the observed group of SMEs (Oakland, 2004). The processes in this type of organization are: management $(p=1)$, production $(p=2)$, marketing and sales $(p=3)$, purchase $(p=4)$, design and development $(p=5)$, and support processes $(p=6)$.
The ORFs of SMEs in processing industry are presented in (Aleksić et al, 2013). These factors are:

- planning strategies - the factor whose influence is dominant in the process of management and strategy activities;

- the capability and capacity of internal resources the factor scoped to internal processes;

- the internal situation monitoring and reporting the factor integrated into internal processes;

- human factors - the factor whose influence is dominant in the scope of human resources;

- quality - the factor integrated into all business processes;

- the external situation monitoring and reporting the factor integrated into the external processes;

- the capability and capacity of external resources the factor scoped to external processes;

- the design factor - the factor integrated into manufacturing operations;

- a detection potential - the factor whose influence is dominant in processes sensitive to deviations from desired goals;

- an emergency response - the factor whose influence is dominant in the period of a crisis;

- a safety management system - the factor integrated into the activities related to the safety of employees and company property.

All the considered SMEs are sorted out according to the annual income of the monotonous descending order. According to the result of the classification, 5 SMEs belong to Group A, 19 SMEs belong to Group B whereas Group C consists of 29 SMEs. The weights of the given groups of SMEs are determined with respect to the knowledge and experience of experts analyzing the strength of the enterprises influence on the realization of the country development strategy.

In this case, the weights of the groups are $w_{A}=0.45$, $w_{B}=0.35, w_{C}=0.2$.

The element values of the constructed fuzzy pairwise comparison matrices are given by applying the proposed Algorithm (Step 1 to Step 3). The developed procedure is illustrated by an example of the real-life 
of the management process $(\mathrm{p}=1)$ and the marketing and sales process $(\mathrm{p}=2)$.

The relative importance of the two considered business processes is assessed by the management teams of the SMEs belonging to the following groups: medium importance, high importance $\mathrm{x} 3$ and very high importance. The fuzzy rating of the Group B management teams are: low importance $x 2$, medium importance $x 4$, high importance $x 10$ and very high importance $x 4$. The fuzzy ratings of the Group C management teams are: medium importance $x 11$, high importance $x 11$ and very high importance $x 5$.

The relative importance of the considered business processes for each group is as follows:

$$
\begin{aligned}
& \tilde{W}_{12}^{A}=\frac{1}{5} \cdot\left(\tilde{R}_{3}+3 \cdot \tilde{R}_{4}+\tilde{R}_{5}\right)=(2.8,4,5), \\
& \tilde{W}_{12}^{B}=\frac{1}{19} \cdot\left(\tilde{R}_{2}+4 \cdot \tilde{R}_{3}+10 \cdot \tilde{R}_{4}+4 \cdot \tilde{R}_{5}\right)= \\
& =(2.68,3.89,4.89) \\
& \tilde{W}_{12}^{C}=\frac{1}{29} \cdot\left(11 \cdot \tilde{R}_{3}+11 \cdot \tilde{R}_{4}+5 \cdot \tilde{R}_{5}\right)=(2.21,3.52,5) .
\end{aligned}
$$

The relative importance of the management process $(p=1)$ and the relative importance of the marketing and sales process $(p=2)$ for all the 53 SMEs in processing industry can be calculated as:

$$
\tilde{w}_{12}=0.45 \cdot \tilde{W}_{12}^{A}+0.35 \cdot \tilde{W}_{12}^{B}+0.2 \cdot \tilde{W}_{12}^{C}=(2.28,3.87,5)
$$

In a similar way, the element values of the constructed fuzzy pair-wise comparison matrices are calculated.

The developed procedure of the proposed Algorithm (Step 4 to Step 6) is illustrated by example for checking the consistency of the pair-wise comparison matrix of the relative importance of the considered business processes.

By using the proposed Algorithm (Step 4), the crisp pair-wise comparison matrix of the relative importance of the business processes is given:

$$
W_{p}=\left[\begin{array}{cccccc}
1 & 3.87 & 4.39 & 3.82 & 1.97 & 2.28 \\
0.53 & 1 & 1.35 & 0.98 & 0.44 & 0.99 \\
0.23 & 0.74 & 1 & 0.58 & 0.39 & 0.43 \\
0.26 & 1.02 & 1.72 & 1 & 0.64 & 1.89 \\
0.51 & 2.27 & 2.56 & 1.57 & 1 & 3.97 \\
0.44 & 1.01 & 2.33 & 0.53 & 0.25 & 1
\end{array}\right]
$$

Let us check to consistency of the above fuzzy matrix (Step 5 of the proposed Algorithm).

$W_{p}^{\text {nor }}=\left[\begin{array}{llllll}0.337 & 0.391 & 0.329 & 0.450 & 0.420 & 0.215 \\ 0.178 & 0.101 & 0.101 & 0.116 & 0.094 & 0.094 \\ 0.077 & 0.075 & 0.075 & 0.068 & 0.083 & 0.041 \\ 0.088 & 0.103 & 0.129 & 0.118 & 0.136 & 0.179 \\ 0.172 & 0.229 & 0.192 & 0.185 & 0.213 & 0.376 \\ 0.148 & 0.102 & 0.175 & 0.062 & 0.053 & 0.095\end{array}\right]$

$$
\left(w_{p}\right)^{\prime}=\left[\begin{array}{l}
0.357 \\
0.114 \\
0.070 \\
0.125 \\
0.259 \\
0.106
\end{array}\right] \text {. }
$$

Applying the proposed algorithm for checking matrix consistency started in (Harker, 1988), the weights vector in the first iteration is calculated:

$$
\begin{aligned}
& w_{p}^{1}=\frac{A \cdot e}{e^{T} \cdot A \cdot e}= \\
& =\left[\begin{array}{llllll}
0.347 & 0.106 & 0.067 & 0.131 & 0.238 & 0.111
\end{array}\right]^{T}
\end{aligned}
$$

It is obvious that consistency has not been achieved in the first operation. Continuing this process, we have thus the process has converged in five iterations:

$$
w_{p}=\left[\begin{array}{llllll}
0.361 & 0.098 & 0.071 & 0.129 & 0.236 & 0.105
\end{array}\right]^{T}
$$

Checking the consistency of the pair-wise matrices of the preference of the ORFs under each business process is performed by using the procedure presented in Step 4 of the proposed Algorithm.

The obtained results accounted for by applying the proposed Algorithm (Step 1 to Step 6) are presented in Table 2. 
Table 2 The business process weights and priorities of ORFs under each business process

\begin{tabular}{|c|c|c|c|c|c|c|}
\hline & $p=1$ & $p=2$ & $p=3$ & $p=4$ & $p=5$ & $p=6$ \\
\hline $\mathrm{i}=1$ & 0.011 & 0.036 & 0.027 & 0.04 & 0.059 & 0.06 \\
\hline $\mathrm{i}=2$ & 0.033 & 0.045 & 0.039 & 0.102 & 0.053 & 0.072 \\
\hline$i=3$ & 0.074 & 0.088 & 0.036 & 0.071 & 0.066 & 0.074 \\
\hline$i=4$ & 0.077 & 0.074 & 0.088 & 0.072 & 0.074 & 0.091 \\
\hline$i=5$ & 0.173 & 0.129 & 0.150 & 0.104 & 0.121 & 0.167 \\
\hline$i=6$ & 0.041 & 0.092 & 0.155 & 0.059 & 0.041 & 0.056 \\
\hline $\mathrm{i}=7$ & 0.126 & 0.114 & 0.091 & 0.104 & 0.117 & 0.096 \\
\hline $\mathrm{i}=8$ & 0.083 & 0.075 & 0.055 & 0.090 & 0.112 & 0.09 \\
\hline$i=9$ & 0.185 & 0.189 & 0.230 & 0.209 & 0.141 & 0.122 \\
\hline $\mathrm{i}=10$ & 0.039 & 0.050 & 0.023 & 0.047 & 0.095 & 0.065 \\
\hline $\mathrm{i}=11$ & 0.157 & 0.105 & 0.106 & 0.102 & 0.120 & 0.108 \\
\hline $\begin{array}{l}\text { The business pro- } \\
\text { cess weights }\end{array}$ & 0.361 & 0.098 & 0.071 & 0.129 & 0.236 & 0.105 \\
\hline
\end{tabular}

Source: Authors

The composite priorities are calculated by using the proposed Algorithm (Step 7 to Step 8).

Based on the calculated values of the combined index of priorities, it can be concluded that the ORFs with the biggest impact on the organizational resilience

Table 3 The values of the composite priorities and rank of the ORFs

\begin{tabular}{lcc}
\hline & $r_{i}$ & Rank \\
\cline { 2 - 3 } $\mathrm{i}=1$ & 0.1480 & 1 \\
$\mathrm{i}=2$ & 0.0533 & 10 \\
$\mathrm{i}=3$ & 0.070 & 7 \\
$\mathrm{i}=4$ & 0.078 & 6 \\
$\mathrm{i}=5$ & 0.146 & 2 \\
$\mathrm{i}=6$ & 0.058 & 8 \\
$\mathrm{i}=7$ & 0.114 & 4 \\
$\mathrm{i}=8$ & 0.089 & 5 \\
$\mathrm{i}=9$ & 0.0348 & 11 \\
$\mathrm{i}=10$ & 0.056 & 9 \\
$\mathrm{i}=11$ & 0.127 & 3 \\
\hline
\end{tabular}

Source: Authors of the process industry SMEs are the planning strategies ( $i=1)$ and the quality $(i=5)$. The obtained result shows that, in the first place, it is necessary to deploy management initiatives that should lead to an increase in the two named ORFs, e.g.: a continuous process of improvement, an improvement of communication between all employees in the company, or an improvement of communication between the management teams and stakeholders. The effectiveness of management measures is empowered if the enterprise uses information and communication technology (ICT). On the other hand, the ORF, designated as a potential detection ( $i=9)$, has the smallest impact on organizational resilience, which is realistic due to the fact that the considered SME quality system does not contain a large number of procedures with respect to the size of the enterprise.

\section{CONCLUSION}

Changes occurring in an uncertain business environment require that new management concepts whose task is to increase the effectiveness of the business and sustainability goals of an organization over time should be developed and implemented. 
The first hypothesis is confirmed according to the requirements of the ASIS SPC.1-2009 standard compatible with the series of the ISO 9001, ISO 14001 and ISO 27001 standards. The number of the ORFs, measured in this paper within the scope of organizational resilience, is defined in terms of the discussed organization types, according to Aleksić et al (2013). The second hypothesis is theoretically accurate but it should be confirmed in a future practice since the measures for redefining the strategy should bring results in the following period.

Modelling the relative importance of the business processes and the relative preference of the ORFs is based on the usage of the fuzzy sets. The fuzzy approach is easy to understand, flexible and tolerant to inaccurate data.

The evaluation and ranking of the ORFs represent one of the most important management problems of organizational resilience in all organizations in a changing and uncertain environment. According to the authors, the proposed fuzzy AHP is an appropriate method for determining the rank of the ORFs in an exact way. The priority obtained is less burdened by the subjective attitudes of decision makers, stakeholders and so forth, so it can be considered that an improvement of the strategy effectiveness will be higher, which is one of the main objectives of the management team of any enterprise engaged in various economic activities.

The contributions of this paper can be expressed as follows: (1) identifying the business processes and the ORFs for process industry SMEs, (2) the treatment of uncertainty in the relative importance of relations between business processes and the relative priorities of ORFs was performed by using the fuzzy sets theory, (3) the aggregation of the management teams' assessment into the group consensus is obtained by applying an operator of the fuzzy-weighted mean value, (4) the ranking of the selected ORFs corresponds to the values of the combined priorities index, and (5) the rank of ORFs allows enterprises to learn over time, which increases the effectiveness of their business processes and continuous development.

Apart from the presented advantages, the proposed model has certain limitations. It can be extended in terms of the better structuring of business processes, increasing the number of ORFs depending on the size of the enterprise and/or the types of the economic activity realized within the enterprise. All of these extensions can easily and quickly be incorporated into the proposed model and do not increase the complexity of mathematical computation.

The proposed model is tested on the group of small and medium enterprises in the process industries operating in central Serbia.

A continuous improvement of business processes (which is one of the basic requirements of ISO 9000:2008) is achieved by developing and applying appropriate strategies for improving each group of the identified indicators measuring the effectiveness of business processes. The results of good practice show that the application of management initiatives, based on the priority indicators, enables an improvement of a business process realized in a shorter period of time and at a significantly lower cost. Priority indicators, for example the ORFs, can be determined in an exact manner, for example by using the method proposed in this paper.

Future research will be focused on the development and/or modification of the approaches that can be found in the reference literature for the processing of fuzzy matrix uncertainties existing in the considered problem. By applying new approaches, the ranking of ORFs is obtained, based on which management teams can make a better analysis of their priorities. The identification of ORFs and the determination of their priorities in public enterprises and service-oriented enterprises are also within the scope of a further research. In the authors' opinion, the development of the software based on the model may provide a fast and efficient analysis of ORFs priorities in different enterprises.

\section{ACKNOWLEDGEMENT}

The research presented in this paper was supported by the Ministry of Science and Technological Development of the Republic of Serbia, Grant III-44010. 


\section{REFERENCES}

Adger, W. N. (2000). Social and ecological resilience: are they related? Progress in Human Geography, 24(3), 347-364.

Afgan, N. H., Hovanov, N., \& Andre, P. M. (2009). Sustainable management organization with example of passenger car sustainability assessment. International Journal for Quality Research, 3(2), 159-169.

Aleksić, A., Stefanović, D., Arsovski, S., \& Tadić, D. (2013). (In press). An assessment of organizational resilience potential in SMEs of the process industry: A fuzzy approach. Journal of Loss Prevention in the Process Industries, doi: 10.1016/j. jlp.2013.06.004.

Bass, M. S., \& Kwakernaak, H. (1977). Rating and ranking of multiple-aspect alternatives using fuzzy sets. Automatica, 3, $47-58$.

Bortolan, G., \& Degani, R. (1985). A review of some methods for ranking fuzzy subsets. Fuzzy Sets and Systems, 29, 145-153.

Bozbura, T. F., \& Beskese, A. (2007). Prioritization of organizational capital measurement indicators using fuzzy AHP. International Journal of Approximate Reasoning, 44(2), 124-147.

Carvalho, P., dos Santos, I., Gomes, J., \& Borges, M. (2008). Micro incident analysis framework to assess safety and resilience in the operation of safe critical systems: A case study in a nuclear power plant. Journal of Loss Prevention in the Process Industries, 21, 277-286.

Chan, J. (2011). Enhancing organisational resilience: application of viable system model and MCDA in a small Hong Kong company. International Journal of Production Research, 49(18), $5545-5563$.

Chang, D. Y. (1996). Applications of the extent analysis method on fuzzy AHP. European Journal of Operational Research, 95, 649-655.

Dinh, L., Pasman, H., Gao, X., \& Mannan, M. S. (2012). Resilience engineering of industrial processes: Principles and contributing factors. Journal of Loss Prevention in the Process Industries, 25, 233-241.

Dubois, D., \& Prade, H. (1980). Fuzzy Sets and Systems: Theory and Applications. London, UK: Academic press, INC (LONDON) LTD.

Folke, C. (2006). Resilience: The emergence of a perspective for, social-ecological systems analyses. Global Environmental Change, 16, 253-267.
Harkar, P. T. (1987). Derivatives of the Perron root of a positive reciprocal matrix: with application to the Analytic Hierarchy Process. Applied Mathematics and Computation, 22, 217-232.

Hollnagel, E., Woods, D. D., \& Leveson, N. (2006). Resilience engineering: concepts and precepts. Aldershot, USA: Ashgate.

Hwang, C. L., \& Yoon, K. (1981). Multiple Attribute Decision Making-Methods and Applications. Heidelberg, Germany: Springer Verlag.

Klir, G. J., \& Folger, T. A. (1988). Fuzzy Sets, Uncertainty and Informations. New Jersy, USA: Prentice-Hall, Englewood Cliffs.

Klir, G. J., \& Yuan, B. (1995). Fuzzy Sets and Fuzzy Logic, Theory and Applications. New Jersy, USA: Prentice Hall.

Kong, F., \& Liu, H. (2005). Applying fuzzy Analytic Hierarchy Process to evaluate success factors of e-commerce. International Journal of Information and Systems Sciences, 183(4), 406-412.

Kwong, C. K., \& Bai, H. (2003). Determining the importance weights for the customer requirements in QFD using a fuzzy AHP with an extent analysis approach. IIE Transaction, 35(7), 619-626.

Lee, Y., Shin, J., \& Park, Y. (2012). The changing pattern of SME's innovativeness through business model globalization. Technological Forecasting \& Social Change, 79, 832-842.

Lengnick-Hall, C. A., Beck, T. E., \& Lengnick-Hall, M. L. (2011). Developing a capacity for organizational resilience through strategic human resource management. Human Resource Management Rewiev, 21, 243-255.

Merigó, J. M., \& Casonovas, M. (2008). Using fuzzy numbers in heavy aggregation operators. International Journal of Information Technology, 4, 177-182.

Oakland, J. (2004). Oakland on Quality Management. Boston, USA: Elsevier Butterworth - Heinemann.

Pendall, R., Foster, K., \& Cowell, M. (2010). Resilience and regions: building understanding of the metaphor. Cambridge Journal of Regions, Economy and Society, 3, 71-84.

Saaty, T. L. (1990). How to make a decision: The Analytic Hierarchy Process. European Journal of Operational Resarch, 48, 9-26.

Spekman, R., \& Davis, E. (2004). Risky business: expanding the discussion on risk and the extended enterprise. International Journal of Physical Distribution and Logistics Management, 34(5), 414-433. 
Tadić, D., Gumus, T. A., Arsovski, S., Aleksić, A., \& Stefanović, M. (2013). An evaluation of quality goals by using fuzzy AHP and fuzzy TOPSIS methodology. Journal of Intelligent $\mathcal{E}$ Fuzzy Systems, 25, 547-556. doi:10.3233/IFS-120659.

Torfi, F. R. Z., Farahani, R. Z., \& Rezapour, S. (2010). Fuzzy AHP to determine the relative weights of evaluation criteria and fuzzy TOPSIS to rank the alternatives. Applied Soft Computing, 10, 520-528.

Vargas, L. G. (1982). Reciprocal matrices with random coefficients. Mathematical Modelling, 3, 69-81.

Vidal, M., Carvalho, P., Santos, M., \& dos Santos, I. (2009). Collective work and resilience of complex systems. Journal of Loss Prevention in the Process Industries, 22, 516-527.

Vossen, R. W. (1998). Relative strengths and weaknesses of small firms in innovation. International Small Business Journal, 16, 88-94.
Weeck M., Klocke, F., Schell, H., \& Ruenauver, E. (1997). Evaluating alternative production cycles using the extended fuzzy AHP method. European Journal of Operational Research, 100(2) 351-365.

Wymenga, P., Spanikova, V., Barker, A., Konings, J., \& Canton, A. (2012). EU SMEs in 2012: at the crossroads Annual report on small and medium-sized enterprises in the EU, 2011/12, Ecorys, Rotterdam.

Xi, X., \& Qin, Q. (2013). Product quality evaluation system based on AHP fuzzy comprehensive evaluation. Journal of Industrial Engineering and Management, 6(1), 356-366.

Zadeh, L. A. (1975). The concept of a linguistic variable and its application to approximate reasoning. Information Sciences, 8(3), 199-249.

Zimmermann, H. J. (2001). Fuzzy Set Theory and its Applications. Boston, USA: Kluwer Nijhoff Publishing.

Received on $10^{\text {th }}$ October 2013, after revision, accepted for publication on $17^{\text {th }}$ December 2013

Danijela Tadic is a full professor at the Faculty of Engineering, University of Kragujevac. She optained her PhD degree at the Mechanical faculty, University of Belgrade. She has authored or coauthored 10 textbooks and scientific monographs, 14 papers published in the SCI list journals and more than 40 papers published at national and international conferences.

Aleksandar Aleksic is a research associate at the Center for Quality at the Faculty of Engineering, University of Kragujevac, Kragujevac where he received his PhD degree. Since 2008, he has been involved in the process of teaching the subjects: Fundamentals of Entrepreneurial Management and Economics, Engineering Economy, and Management Communications. He has authored or coauthored 1 scientific monograph, 5 papers published in the SCI list journals and more than 30 papers published at national and international conferences. 


\section{APPENDIX: COMPARISON OF FUZZY NUMBERS}

In this Appendix, a simple method of comparing fuzzy numbers and determining A degree of belief that one fuzzy number is greater than or equal to one is given (Bass \& Kwakernaak, 1977; Dubois \& Prade, 1980).

Let $\tilde{A}$ and $\tilde{B}$ be two fuzzy numbers with their supports defined on R:

$\tilde{A}=\left(x ; l_{1}, m_{1}, u_{1}\right)$ and $\tilde{B}=\left(y ; l_{2}, m_{2}, u_{2}\right)$

Where $l_{1}, l_{2}, u_{1}, u_{2}$, are lower and upper bounds and $m_{1}, m_{2}$, are modal values of $\tilde{A}$ and $\tilde{B}$, respectively. Let $m_{2}<m_{1}$ and $l_{2}<l_{1}$ and $u_{2}<u_{1}$.

The degree of belief that $\tilde{B}$ is greater than or equal to $\tilde{A}$ is denoted by $\operatorname{Bel}(\tilde{B} \geq \tilde{A})$, which is given using the operation max and min (Dubois \& Prade, 1980):

$\operatorname{Bel}(\tilde{B} \geq \tilde{A})=\operatorname{supmin}_{x \geq y}\left(\mu_{\tilde{A}}(x), \mu_{\tilde{B}}(y)\right)$

The expression can be defined as:

1. Bel $(\tilde{A} \geq \tilde{B})=1$, because $\mu_{\tilde{A}}\left(m_{1}\right)=1$ and $\mu_{\tilde{B}}\left(m_{2}\right)=1$

and $m_{1}>m_{2}$

2. At the same time, $\operatorname{Bel}(\tilde{B} \geq \tilde{A})$ is equal to the ordinate of point $\mathrm{D}$, which belongs to both $\tilde{A}$ and $\tilde{B}$, i.e. it is the supremum of intersection:

$\operatorname{Bel}(\tilde{B} \geq \tilde{A})=$ the ordinate of point D.

When $\tilde{A}$ and $\tilde{B}$ are triangular fuzzy numbers, the ordinate of $\mathrm{D}$ is given by the equation:

$$
\operatorname{Bel}(\tilde{B} \geq \tilde{A})=\frac{l_{1}-u_{2}}{\left(m_{2}-u_{2}\right)-\left(m_{1}-l_{1}\right)}
$$

For the full understanding of the risk analysis presented in this paper, it is important that the degree of belief that fuzzy number $\tilde{A}$ is bigger than/equal to $\mathrm{K}$ fuzzy numbers $\tilde{B}_{1}, \ldots, \tilde{B}_{k}, \ldots, \tilde{B}_{K},($ Bass \& Kwakernaak, 1977) should be determined:

$$
\begin{aligned}
& \operatorname{Bel}\left(\tilde{A} \geq\left(\tilde{B}_{1}, \ldots, \tilde{B}_{k}, \ldots ., \tilde{B}_{K}\right)\right)= \\
& =\sup _{t \geq t_{1}} \min \left(\mu_{\tilde{A}}(t), \mu_{\tilde{B}_{1}}\left(t_{1}\right), \ldots, \mu_{\tilde{B}_{k}}\left(t_{k}\right), \ldots, \mu_{\tilde{B}_{K}}\left(t_{K}\right)\right) \\
& \quad \ldots . . \\
& \quad t \geq t_{k} \\
& \quad \ldots . \\
& t \geq t_{K} \\
& \operatorname{Bel}\left(\left(\tilde{A} \geq \tilde{B}_{1}\right), \text { and }\left(\tilde{A} \geq \tilde{B}_{2}\right), \ldots,\left(\tilde{A} \geq \tilde{B}_{k}\right), \ldots,\left(\tilde{A} \geq \tilde{B}_{K}\right)\right)= \\
& \min _{k=1, . ., K} \operatorname{Bel}\left(\tilde{A} \geq \tilde{B}_{k}\right)
\end{aligned}
$$




\title{
RANGIRANJE FAKTORA KAPACITETA ZA OPORAVAK PREDUZEĆA POMOĆU MODIFIKOVANOG FAZI ANALITIČKOG HIJERARHIJSKOG PROCESA
}

\author{
Danijela Tadić, ${ }^{*}$ Aleksandar Aleksić \\ Fakultet inženjerskih nauka Univerziteta u Kragujevcu
}

Poslednjih decenija razvijen je koncept kapaciteta za oporavak organizacija usled naglog pada vrednosti performansi, koji predstavlja adekvatan menadžment metod posebno za preduzeća koja posluju u uslovima ekonomske krize. U ovom radu razmatran je problem određivanja prioriteta faktora kapaciteta za oporavak organizacija (FKPO) koji predstavlja prvi korak u određivanju strategije poboljšanja. Rangiranje FKPO je postavljeno kao zadatak višekriterijumske optimizacije koji uključuje kvalitativne promenljive. Menadžment timovi, na nivou svakog preduzeća, procenjuju relativnu važnost svakog para poslovnih procesa i preferentnost FKPO unutar svakog poslovnog procesa pomoću unapred definisanih lingvističkih iskaza. Modeliranje lingvističkih iskaza zasnovano je na teoriji fazi skupova. Agregirane vrednosti razmatranih veličina dobijene su primenom operatora otežane fazi srednje vrednosti. Vektor kombinovanog prioriteta FKPO-a određen je primenom fazi Analitičkog Hijerarhijskog Procesa. Predloženi model je ilustrovan primerom u kojem su korišćeni podaci dobijeni iz procesnih malih i srednjih preduzeća koja posluju u Centralnoj Srbiji. Pokazano je da je razvijeni model veoma pogodan za donošenje odluka o promeni poslovne strategije, sa ciljem povećanja kapaciteta za oporavak organizacija.

Ključne reči: faktori kapaciteta za oporavak organizacija, fazi skup, operator otežane fazi srednje vrednosti (Fuzzy Ordered Weighted Averaging Operator - FOWA), fazi Analitički Hijerarhijski Proces (FAHP)

JEL Classification: C61, D80, 021

\section{UVOD}

$\mathrm{Na}$ osnovu rezultata dobre prakse, može se reći da je gotovo nemoguće identifikovati sve potencijalne faktore koji mogu da dovedu do nastajanja jednog, ili više, rizika poslovanja organizacije (Spekman, 2004). Savremeno poslovanje je postalo veoma kompleksno,

\footnotetext{
* Korespondencija: D. Tadić, Fakultet inženjerskih nauka Univerziteta u Kragujevcu, Sestre Janjić 6, 34000 Kragujevac, Srbija; e-mail: galovic@kg.ac.rs
}

što je uzrokovano razvojem novih tehnologija, prvenstveno informacionih i komunikacionih tehnologija (Information Commuinication Technologies - ICT). Kompleksni i promenljivi tržišni uslovi predstavljaju značajne faktore rizika kojima treba upravljati dugoročno kako bi se obezbedio održivi razvoj organizacije (Afgan et al, 2009). Identifikacija, procena $\mathrm{i}$ upravljanje rizicima, $\mathrm{u}$ gotovo svim organizacijama, zasnovani su na primeni standarda za menadžment rizikom (principi i uputstva) - ISO 31000:2008 i standarda za menadžment kontinuitetom 
poslovanja - BS 25999:2006. U novije vreme, pokazano je da primena ovih standarda nije dovoljna za uspešno upravljanje rizicima, jer $\mathrm{u}$ organizacijama mogu da nastanu veoma ozbiljni rizici zbog kojih menadžment nije u mogućnosti da obezedi održivi razvoj.

Predmet istraživanja u ovom radu je identifikovanje i rangiranje faktora kapaciteta za oporavak organizacije (FKPO) usled naglog pada performansi. Ovi faktori daju jasnu tržišnu poziciju organizacije, a rang FKPO pruža mogućnost svakoj organizaciji da uči na osnovu iskustava drugih sličnih organizacija.

Organizacije razmatrane $u$ ovom radu pripadaju grupi malih i srednjih preduzeća procesne industrije. Procesna industrija se može posmatrati kao proizvodna industrija u kojoj se koriste tečni sirovinski materijali za proizvodnju gotovih proizvoda, pri čemu je obezbeđen kontinualni procesni tok sirovina. Takođe, treba napomenuti da se finalni proizvodi koji nastaju u procesnoj industriji ne mogu rastaviti na sirovine od kojih su napravljeni. Imajući u vidu neprekidnost i međusobnu povezanost procesa, veoma je važno unaprediti kapacitet za oporavak procesnih organizacija.

Iako postoji određeni broj velikih multinacionalnih orgnizacija iz oblasti procesne industrije, koje poseduju dovoljno resursa da bi se održale na tržištu, veliki broj organizacija procesne industrije spada u grupu malih i srednjih preduzeća (MSP). Karakteristike MSP mogu se iskazati na sledeći način (Član 2 Aneksa preporuka 2003/361/EC): Broj zaposlenih u MSP-a je manji od 250, godišnji prihod jednog MSP nije veći od 50 miliona eura, i/ili poslovna imovina iskazana u bilansu stanja je manja ili jednaka 43 miliona eura. Jasno je da su MSP prepoznata kao važan privredni sektor za zemlje u razvoju, kao i za razvijene zemlje, koje imaju nameru da stimulišu preduzetnički duh koji dovodi do: (a) otvaranja novih radnih mesta $u$ procesnoj industriji, (b) poboljšavanja kvaliteta proizvoda, (c) razvoja novih istraživanja čiji rezultati treba da unaprede procese procesne industrije, (d) korišćenja naprednih tehnologija (eko-inovacije, zelena tehnologija i sl.) i (e) stvaranja novih tržišta.

Cilj istraživanja $u$ radu može se definisati kao određivanje prioriteta menadžment inicijativa na egzaktan način koje treba da dovedu do unapređenja performansi organizacije i njene veće održivosti tokom vremena. Održivi razvoj kompleksnog sistema ostvaruje se kroz konstantnu interakciju poslovnih procesa i okruženja. Kako svaka organizacija posluje $u$ veoma promenljivom okruženju, od menadžmenta se očekuje da bude sposoban da brzo adaptira organizaciju na nove uslove poslovanja, odnosno, da organizacija ima visok nivo kapaciteta za oporavak kako bi upešno odgovorila na nastale promene.

U ovom radu definisane su dve osnovne hipoteze: (1) nivo kapaciteta za oporavak procesnih MSP-a može da se odredi pomoću 11 FKPO-a, (2) redefinisanje strategije za poboljšanje poslovanja preduzeća $u$ promenljivom okruženju zasnovano je na dobijenom rangu FKPO-a.

U raznolikim menadžment problemima preduzeća, kao što je problem upravljanja kapacitetom za oporavak MSP-a koji je razmatran u ovom radu, postoji veliki broj različitih promeljivih. Vrednosti upravljačkih promenljivih zasnovane su na procenama donosilaca odluka. S obzirom na to da se poslovno okruženje brzo i neprekidno menja, realna je pretpostavka da je gotovo nemoguće vrednosti promenljivih opisati preciznim brojevima. Opisivanje neizvesnih i nepreciznih vrednosti pomoću lingvističkih iskaza od strane donosilaca odluka bliže je ljudskom načinu razmišljanja. U literaturi postoje brojne matematičke teorije kojima se lingvistički iskazi dovoljno dobro kvantitativno opisuju, a takve su teorija verovatnoće, teorija fazi skupova, teorija grubih skupova i dr. H. J. Zimmermann (2001) smatra da je modeliranje lingvističkih iskaza najprikladnije izvršiti primenom teorije fazi skupova. U ovom radu, sve neizvesnosti i nepreciznosti $u$ relativnim važnostima poslovnih procesa i relativnim preferentnostima FKPO-a unutar svakog poslovnog procesa, opisuju se lingvističkim varijablama (Zadeh, 1975) koje su modelirane trougaonim fazi brojevima (Klir \& Folger, 1988; Zimmeramnn, 2001).

Rešenje razmatranog problema dobijeno je pomoću proširenog fazi Analitičkog Hijerarhijskog Procesa (FAHP). Rang FKPO-a predstavlja ulazne informacije za proces redefinisanja strategije poboljšanja poslovanja razmatrane vrste MSP-a.

Rad je organizovan na sledeći način: pregled literature iz referentnih domena je prikazan u Odeljku 2. 
Modeliranje neizvesnosti je opisano u trećem odeljku. U Odeljku 4 prikazana je proširena fazi AHP metoda za rangiranje FKOP-a sa respektovanjem svih poslovnih procesa kao njihovih težina. U Odeljku 5 dat je primer kojim se ilustruje razvijena metoda. U primeru se koriste podaci dobijeni iz procesnih MSP-a, koja posluju u Centralnoj Srbiji. Zaključci su prikazani u Odeljku 6.

\section{PREGLED LITERATURE}

Kapacitet za oporavak može da se analizira u različitim istraživačkim domenima, na primer, u domenu eko sistema (Folke, 2006), u domenu socio-ekonomskih sistema (Adger, 2000). U oblasti inženjerstva, kapacitet za oporavak se definiše kao sposobnost da se osete i prepoznaju promene, poremećaji, prekidi, nakon čega se sistem adaptira i apsorbuje iste (Hollnagel et al, 2006). Navedene razlike, $u$ tome šta sve podrazumeva kapacitet za oporavak, nisu dozvolile postizanje naučnog konsenzusa o konstitutivnim elementima kapaciteta za oporavak organizacija, kao ni odgovarajuću metodologiju za procenu istog.

Različiti faktori (razvoj novih tehnologija, globalizacija, i sl.), uticali su na povećanje očekivanja kupaca širom sveta. U tom smislu, preduzeća iz grupe MSP moraju da budu inovativna i da se prilagode nastalim izazovima (Lee et al, 2012). Da bi se to postiglo, menadžment MSP-a mora da kombinuje stare i nove poslovne modele i $\mathrm{da}$, istovremeno, unapređuje sopstveni kapacitet za oporavak. To je veoma značajno jer MSP sektor čini značajni deo privrednog sistema u državama Evropske unije (EU). Tako, na primer, $99.8 \%$ preduzeća je bilo iz grupe MSP 2012. godine (Wymenga et al, 2012). Podatak iz 2012. godine pokazuje da u MSP-a koja egzistiraju u EU radi oko $67.4 \%$ radnika. Unapređenje kapaciteta za oporavak MSP-a determinisano je tržištem i osobinama samog preduzeća. Ovakva preduzeća imaju ograničen pristup resursima (Vossen, 1998), što ih čini otvorenim i ranjivim u odnosu na eksterne entitete, tako da moraju definisati odgovarajuću strategiju i obezbediti resurse za unapređenje kapaciteta za oporavak.

Upravljanje kapacitetom za oporavak može da se postigne primenom adekvatne poslovne strategije, koja u velikoj meri utiče na održivost MSP-a, i ima dugoročan uticaj na njegove poslovne performanse (Lengnick-Hall et al, 2011). Ukoliko se uzme u obzir delovanje ljudskih resursa unutar organizacije, koncept kapaciteta za oporavak bi trebalo da bude implementiran od strane lidera. Upravo unapređenje $\mathrm{u}$ oblasti ljudskih resursa treba da rezultira unapređenjem kapaciteta za oporavak organizacije.

U procesnoj industriji, kapacitet za oporavak je relativno poznat koncept $u$ velikim i multinacionalnim organizacijama. Jedan od osnovnih izazova kapaciteta za oporavak je sposobnost da se sprovodi praćenje sistema u kontinuitetu, što podrazumeva praćenje određenih FKPO sa ciljem određivanja ograničenja i pozicije sistema (Vidal et al, 2009). Postoji veliki broj MSP-a koja iskazuju potrebu za jednostavnim i pouzdanim alatom za procenu kapaciteta za oporavak.

Kapacitet za oporavak organizacija može biti tretiran kao fazi problem (Pendall et al, 2010), s obzirom na to da se veliki broj događaja koji utiču na njega opisuje neizvesnim i nepreciznim podacima (na primer, nagli poremećaji ili veoma spore promene). Da bi izmerena veličina bila konzistentna tokom vremena, procena treba da bude izvršena na nivou poslovnih procesa. Faktori koji doprinose kapacitetu za oporavak mogu da budu procenjeni (Dinh et al, 2012), što daje jasnu sliku o stanju procesa i njihovoj sposobnosti za oporavak, ukoliko se desi poremećaj. Postoji veliki broj promenljivih veličina koje utiču kako na kapacitet za oporavak kritičnih procesa (Carvalho et al, 2008), tako i na ukupni kapacitet za oporavak organizacije. Kapaciteti za oporavak organizacija mogu se predstaviti pomoću odgovarajućih modela $u$ kojima egzistiraju promenljive, a koje su modelirane fazi brojevima (Chan, 2011). Osnovni cilj ovog rada je definisanje konceptualnog modela za procenu FKPO-a koji imaju najveći uticaj na kapacitet za oporavak razmatrane grupe preduzeća.

Ocena i rangiranje FKPO u prisustvu neizvesnosti na grupi MSP-a procesne industrije, može se postaviti kao zadatak VKO odlučivanja. Jedna od višekriterijumskih optimizacionih (VKO) metoda, koja se najčešće koristi za rešavanje menadžment problema $\mathrm{u}$ različitim istraživačkim domenima, jeste fazi Analitički Hijerarhijski Proces (FAHP) (Weeck et al, 1997) koji predstavlja proširenje konvencionalnog AHP (Saaty, 
1990). FAHP dozvoljava da se menadžment problemi modeliraju na holistički način, što predstavlja glavnu razliku između FAHP i ostalih VKO metoda.

U literaturi postoje brojni pristupi za obradu FAHP. Jedan od najčešće korišćenih pristupa za obradu FAHP sa trougaonim fazi brojevima razvio je D. Y. Chang (1996). Korišćenje ovog pristupa ne zahteva složena matematička izračunavanja i ima mogućnost da dovoljno dobro podrži ljudski način razmišljanja. Ovaj pristup može lako i jednostavno da se implementira u konvencionalnu AHP (Kwong \& Bai, 2003). Vektor težina poslovnih procesa i vektori prioriteta FKPO-a unutar svakog poslovnog procesa su dobijeni primenom metode za poređenje fazi brojeva (Dubois \& Prade, 1980; Bass \& Kwaakernak, 1977). Prioriteti FKPO-a sa respektovanjem svih poslovnih procesa i njihovih težina računaju se kao $\mathrm{u}$ konvencionalnoj AHP.

U velikom broju radova u kojima se razmatraju različiti menadžment problemi, rešenja su nađena primenom FAHP (Chang, 1996). X. Xi i Q. Qin (2013) razmatraju problem određivanja ukupne ocene kvaliteta svakog proizvoda. Određivanjem priopriteta organizacionih indikatora uspešnosti bave se T. F. Bozbura i A. Beskese (2007). Rangiranje ključnih faktora uticaja u E-poslovanju je razmatrano u radu F. Kong-a i H. Liu-a (2005). U mnogim radovima u kojima se rešenje nalazi primenom dve ili više VKO metode, FAHP je korišćen za nalaženje težina razmatranih veličina (Torfi et al, 2010; Tadić et al, 2013).

Respektujući dobre karakteriste FAHP, autori ovog rada smatraju da ocena i rangiranje FKPO-a može dovoljno dobro da se izvrši primenom proširene FAHP.

\section{MODELIRANJE NEIZVESNOSTI}

U ovom radu lingvistički iskazi su modelirani primenom teorije fazi skupova. Svaki fazi skup je određen funkcijom raspodele mogućnosti i domenom. Oblik funkcije raspodele mogućnosti svakog fazi skupa određen je na osnovu subjektivne procene donosilaca odluka, i zavisi od njihovog konceptualnog znanja, intuicije, iskustva (Zimmermann, 2001). U literaturi se najviše koriste trougaoni i trapezoidni fazi brojevi za modeliranje bilo koje vrste neizvesnosti. Korišćenje ovih fazi brojeva ne zahteva složena matematička izračunavanja, a, s druge strane, tačnost dobijenih rezultata je sasvim zadovoljavajuća. Prema nekim autorima, korišćenje fazi skupova višeg reda (parabola, logaritamska kriva, Belova kriva i dr.) nema značajnu primenu u modeliranju neizvesnosti koje egzistiraju u realnim problemima (Klir \& Yuan, 1995). Domeni fazi skupova mogu da budu definisani na različitim intervalima, na primer standardna skala mera (analogno konvencionalnoj AHP), skala mera koja uključuje realne brojeve na intervalima [0-1] i [15].

\section{Osnovne definicije teorije fazi skupova}

Osnovne definicije teorije fazi skupova su (Dubois \& Prade, 1980; Klir \& Folger, 1988; Zimmermann, 2001):

Definicija 1. Neizvesnost se može definisati kao nedostatak relevantnih informacija na osnovu kojih donosilac odluke može kvalitativno i kvantitativno da opiše promenljivu (Zimmermann, 2001).

Definicija 2. Lingvistička promenljiva je promenljiva koja je iskazana lingvističkim terminima (Zadeh, 1975).

Definicija 3. Fazi skup Ã se definiše kao skup uređenih parova:

$$
\tilde{A}=\left\{x, \mu_{\tilde{A}}(x) \mid x \in X, 0 \leq \mu_{\tilde{A}}(x) \leq 1\right\}
$$

gde: fazi skup $\tilde{A}$ je definisan na skupu realnih brojeva $X \in R$. U opštem slučaju, skup $X$ može da bude konačan i/ili beskonačan. $\mu_{\tilde{A}}(x)$ je funkcija raspodele mogućnosti fazi skupa $\tilde{A}$.

Definicija 4. Fazi broj $\tilde{A}$ je konveksan normalizovan fazi skup $\tilde{A}$ na skupu realnih brojeva R, tako da: (1) ako egzistira neko $\mathrm{x}_{0} \in \mathrm{R}$ i $\mu_{\widetilde{A}}\left(x_{0}\right)=1$, (2) $\mu_{\tilde{A}}(x)$ je kontinualna funkcija.

Definicija 5. Fazi broj $\tilde{A}$ na skupu realnih brojeva $\mathrm{R}$ je trougaoni fazi broj, ako je njegova funkcija $\mu_{\tilde{A}}(x)$ $R \rightarrow[0,1]$ i jednaka je: 
$\mu_{\tilde{A}}(x)=\left\{\begin{array}{cc}\frac{x-a}{m-a} & x \in[a, m] \\ \frac{d-x}{d-m} & x \in[m, d] \\ 0 & \text { ostalo }\end{array}\right\}$.

Definicija 6. Matrica $\tilde{M}$ je nazvana fazi matrica ako je najmanje jedan element matrice $\tilde{M}$ fazi broj (Bortolan \& Degani, 1985).

Definicija 7. Operacije nad fazi skupovima su definisane $u$ (Dubois \& Prade, 1980). Posmatrajmo dva fazi broja $\tilde{A}=\left\{x, \mu_{\tilde{A}}(x) \mid x \in R\right\}$ i $\tilde{B}=\left\{y, \mu_{\tilde{B}}(y) \mid y \in R\right\}$. Funkcije raspodela mogućnosti ovih fazi skupova su neprekidne i definisane su na skupu realnih brojeva u intervalu od 0 do 1 . Neka je sa * označena kontinualna binarna relacija između dva fazi skupa. Tada $\tilde{A} * \tilde{B}$ je fazi skup koji je označen kao $\tilde{C}=\tilde{A} * \tilde{B}$. Vrednosti u domenu fazi skupa $\tilde{C}$, mogu da budu izračunate kao $\mathrm{z}=\mathrm{x}^{*} \mathrm{y}$ i $\mu_{\tilde{C}}(z)=\sup _{z=x^{*} y}\left(\mu_{\tilde{A}}(x), \mu_{\tilde{B}}(y)\right)$

Razmatrajmo dva trougaona fazi broja $\tilde{A}=\left(l_{1}, m_{1}, u_{1}\right)$ i $\tilde{B}=\left(l_{2}, m_{2}, u_{2}\right)$. Algebarska pravila za ova dva fazi broja su:

1. $\left(l_{1}, m_{1}, u_{1}\right)+\left(l_{2}, m_{2}, u_{2}\right)=\left(l_{1}+l_{2}, m_{1}+m_{2}, u_{1}+u_{2}\right)$

2. $\left(l_{1}, m_{1}, u_{1}\right)-\left(l_{2}, m_{2}, u_{2}\right)=\left(l_{1}-u_{2}, m_{1}-m_{2}, u_{1}-l_{2}\right)$

3. $\left(l_{1}, m_{1}, u_{1}\right):\left(l_{2}, m_{2}, u_{2}\right)=\left(l_{1}: u_{2}, m_{1}: m_{2}, u_{1}: l_{2}\right)$

4. $\lambda \cdot\left(l_{1}, m_{1}, u_{1}\right)=\left(\lambda \cdot l_{1}, \lambda \cdot m_{1}, \lambda \cdot u_{1}\right)$

5. $\left(l_{1}, m_{1}, u_{1}\right)^{-1}=\left(\frac{1}{u_{1}}, \frac{1}{m_{1}}, \frac{1}{l_{1}}\right)$

Definicija 8. Defazifikacija je postupak kojim se određuje skalarna vrednost koja na najbolji način reprezentuje fazi skup.

\section{Modeliranje relativnih važnosti poslovnih procesa i relativnih preferentnosti faktora kapaciteta za oporavak organizacija}

Možemo pretpostaviti da poslovni procesi i FKPO-a unutar svakog poslovnog procesa nemaju iste relativne važnosti i da se ne menjaju tokom određenog vremenskog intervala. Vrednosti relativnih važnosti razmatranih veličina su dobijene na osnovu subjektivne procene menadžment timova MSP-a. Donosioci odluka svoje procene zasnivaju na znanju, iskustvu, rezultatima dobre prakse, definisanim poslovnim strategijama i dr.

U ovom radu procene relativne važnosti poslovnih procesa i relativne važnosti FKPO-a su zadate $\mathrm{u}$ formi matrica parova upoređenja (analogno AHP metodi), koji je prema mišljenju autora bliži ljudskom načinu razmišljanja u odnosu na pristup direktne procene. $\mathrm{U}$ konvencionalnoj AHP metodi skala mera je definisana na skupu realnih brojeva koji pripadaju intervalu [1-9]. Korišćenje standardne skale mera je lako i jednostavno, ali nije uvek moguće da donosilac odluke svoje mišljenje koje obuhvata veliki stepen neizvesnosti i nepreciznosti, preslika u precizan broj (Kwong \& Bai, 2003). Relanije je da se uvede pretpostavka da donosioci odluka svoja mišljenja bolje iskazuju pomoću lingvističkih iskaza.

Elementi ovih matrica su lingvistički iskazi koji su modelirani trougaonim fazi brojevima

$W_{p p^{\prime}}^{e}=\left(x ; l_{p p^{\prime}}^{e}, m_{p p^{\prime}}^{e}, u_{p p^{\prime}}^{e}\right)$,

$W_{i i^{\prime}}^{p e}=\left(x ; l_{i i^{\prime}}^{p e}, m_{i i^{\prime}}^{p e}, u_{i i^{\prime}}^{p e}\right)$

$p, p^{\prime}=1, . ., P ; p \neq p^{\prime} ; i, i^{\prime}=1, . ., I ; i \neq i^{\prime} ; e=1, . ., E$

respektivno.

Donje i gornje granice domena razmatranih trougaonih fazi brojeva označene su kao $l_{p p^{\prime}}^{e}, l_{i i^{\prime}}^{p e}, u_{p p^{\prime}}^{e}, u_{i i^{\prime}}^{p e} \quad$ i modalne vrednosti $m_{p p^{\prime}}^{e}, m_{i i^{\prime}}^{p e}$, pripadaju intervalu [1-5]. Vrednost 1 označava da relativna važnost poslovnog procesa $p$, odnosno FKPO i prema poslovnom procesu $p^{\prime}$, odnosno FKPO $i^{\prime}$, respektivno je jednaka. Vrednost 5 označava da poslovni process $p$, odnosno FKPO i, ima ekstremnu relativnu važnost $\mathrm{u}$ odnosu na poslovni proces $p^{\prime}$, odnosno FKPO $i^{\prime}$, respektivno.

Ako je relativna važnost procesa $p$ manja $\mathrm{u}$ odnosu na process $p^{\prime}$, tada je $\mathrm{u}$ fazi matrici relativnog 
odnosa važnosti poslovnih procesa to predstavljeno trougaonim fazi brojem

$\tilde{W}_{p p^{\prime}}^{e}=\left(\tilde{W}_{p p^{\prime}}^{e}\right)^{-1}=\left(\frac{1}{u_{p p^{\prime}}^{e}}, \frac{1}{m_{p p^{\prime}}^{e}}, \frac{1}{l_{p p^{\prime}}^{e}}\right)$.

Na sličan način se razmatra relativna preferentnost FKPO,

$$
\begin{aligned}
& \tilde{W}_{i i^{\prime}}^{p e}=\left(\tilde{W}_{i i^{\prime}}^{p e}\right)^{-1}=\left(\frac{1}{u_{i i^{\prime}}^{p e}}, \frac{1}{m_{i i^{\prime}}^{p e}}, \frac{1}{l_{i i^{\prime}}^{p e}}\right), p, p^{\prime}= \\
& =1, \ldots, P ; p \neq p^{\prime} ; i, i^{\prime}=1, \ldots, I ; i \neq i^{\prime} ; e=1, \ldots, E .
\end{aligned}
$$

Ako je $p=p^{\prime} ; i=i^{\prime}\left(i, i^{\prime}=1, \ldots, I ; p, p^{\prime}=1, \ldots, P\right)$, tada se relativna važnost poslovnih procesa, odnosno, relativna važnost FKPO u odgovarajućim fazi matricama parova upoređenja, može predstaviti brojem 1 koji je trougaoni fazi broj $(1,1,1)$.

U ovom radu, menadžment timovi razmatranih MSP-a koriste pet lingvističkih iskaza koji su modelirani trougaonim fazi brojevima na sledeći način:

veoma mala važnost/preferentnost $-\tilde{R}_{1}=(1,1,2)$

mala važnost/preferentnost - $\tilde{R}_{2}=(1,2,3)$

srednja vrednost/preferentnost $-\tilde{R}_{3}=(1,3,5)$

visoka važnost/preferentnost $-\tilde{R}_{4}=(3,4,5)$

veoma visoka važnost/preferentnost $-\tilde{R}_{5}=(4,5,5)$

\section{METODOLOGIJA}

Proširenje FAHP metode, koja je razvijena u (Chang, 1996), sastoji se u određivanju agregirane vrednosti procena relativne važnosti poslovnih procesa, odnosno, relativnog prioriteta FKPO-a unutar svakog poslovnog procesa. Koncept predložene proširene FAHP prikazan je nadalje.

\section{Matematička postavka problema}

U ovom radu razmatraju se procesna MSP koja se formalno predstavljaju skupom indeksa

$E=\{1, \ldots, e, \ldots, E\}$. Indeks za preduzeće je označen kao e, a ukupan broj razmatranih preduzeća je E.
Menadžment tim svakog razmatranog MSP sastoji se od vlasnika firme, proizvodnog menadžera i finansijskog menadžera. Može se smatrati da menadžment tim na nivou svakog MSP odluke donosi konsenzusom. Sva razmatrana MSP-a su podeljena u grupe koje se formalno predstavljaju skupom indeksa $G=\{1, \ldots, g, \ldots, G\}$. Indeks grupe je označen kao g, a $G$ je ukupan broj grupa MSP-a. U ovom radu klasifikacija MSP-a je izvršena primenom $A B C$ metode koja je zasnovana na Pareto analizi. Tretirana MSP-a primenom $\mathrm{ABC}$ metode su klasifikovane $\mathrm{u}$ tri grupe A, B i C. Kriterijum klasifikacije je ostvarena dobit na godišnjem nivou. Tipično, grupi A pripada 5-10\% svih razmatranih MSP-a koji imaju najveću vrednost kriterijuma klasifikacije. Grupi B pripada oko 15\% svih tretiranih MSP-a. Sva ostala MSP-a pripadaju grupi C. Na osnovu rezultata klasifikacije može se odrediti težina ili važnost, procena menadžment timova razmatranih MSP-a. Važnost procena menadžment timova korespondira važnosti grupa koje su određene u postupku klasifikacije. Najveću važnost imaju menadžment timovi preduzeća koja pripadaju grupi A. Srednju važnost u donošenju odluka imaju menadžment timovi MSP-a koji pripadaju grupi B. Najmanju važnost imaju menadžment timovi preduzeća koji pripadaju grupi C. Važnost procena menadžment timova na nivou grupe, koja je određena u postupku klasifikacije, određuje se na osnovu rezultata dobre prakse. Takođe, važno je napomenuti da procene menadžment timova unutar jedne grupe imaju podjednaku važnost.

Svi poslovni procesi $u$ razmatranim MSP-a predstavljaju se skupom indeksa $P=\{1, \ldots ., p, \ldots, P\}$. Ukupan broj poslovnih procesa je $P$, a $p$ je indeks poslovnog procesa. FKPO-a su predstavljeni skupom indeksa $I=\{1, \ldots ., i, . ., I\}$. Indeks za FKPO je $i$, a $I$ je ukupan broj identifikovanih FKPO-a. Fazi procena relativnih važnosti poslovnih procesa $\mathrm{i}$ relativnih preferentnosti FKPO-a unutar svakog procesa je dobijena od svakog menadžment tima razmatranog MSP. Ove fazi procene su modelirane trougaonim fazi brojevima

$\tilde{W}_{p p^{\prime}}^{e}=\left(x ; l_{p p^{\prime}}^{e}, m_{p p^{\prime}}^{e}, u_{p p^{\prime}}^{e}\right)$

$\tilde{W}_{i i^{\prime}}^{p e}=\left(x ; l_{i i}^{p e}, m_{i i}^{p e}, u_{i i}^{p e}\right)$ 
$p, p^{\prime}=1, . ., P ; p \neq p^{\prime} ; i, i^{\prime}=1, . ., I ; i \neq i^{\prime} ; e=1, . ., E$.

Kako je važnost procena menadžment timova jedne grupe jednaka, tada primenom metode srednje vrednosti mogu se izračunati vrednosti procena unutar jedne grupe MSP-a. Ove vrednosti su modelirane trougaonim fazi brojevima na osnovu pravila fazi algebra (Klir \& Folger, 1988; Zimmermann, 2001). Fazi procene relativnog odnosa važnosti, odnosno preferentnosti svakog para identifikovanih poslovnih procesa, odnosno, svakog para FKPO-a unutar svakog poslovnog procesa na nivou razmatranog uzorka MSP-a, dobijene su primenom metode koja je označena kao otežana fazi srednja vrednost (Fuzzy Ordered Weighted Averaging - FOWA) (Merigó \& Casonovas, 2008). Ove vrednosti su označene kao:

$$
\begin{aligned}
& \tilde{w}_{p p^{\prime}}=\left(x ; l_{p p^{\prime}}, m_{p p^{\prime}}, u_{p p^{\prime}}\right), \tilde{w}_{i i^{\prime}}^{p}=\left(x ; l_{i i^{\prime}}^{p}, m_{i i^{\prime}}^{p}, u_{i i^{\prime}}^{p}\right) \\
& p, p^{\prime}=1, . ., P ; p \neq p^{\prime} ; i, i^{\prime}=1, . ., I ; i \neq i^{\prime} .
\end{aligned}
$$

Koristeći FAHP (Chang, 1996), vektor težina identifikovanih poslovnih procesa, $V_{p}=\left[w_{p}\right]_{1 x P}, p=1, . ., P$ i vektori prefrentnosti FKPO-a unutar svakog poslovnog procesa, $V_{i p}=\left[w_{i p}\right]_{1 x I} ; i=1, \ldots, I ; p=1, . ., P$ su dobijeni. Svakom FKPO pridružena je vrednost kombinovanog indeksa prioriteta $r_{i}, \quad i=1$, .., I na osnovu koje se vrši rangiranje FKPO-a. Na prvom mestu u rangu, odnosno, na poslednjem mestu, nalazi se FKPO kome je pridružena najveća, odnosno, najmanja vrednost $r_{i}, i=1, . .$, I. FKPO koji se nalazi na prvom mestu u rangu ima najveći uticaj na kapacitet za oporavak procesnih MSP-a. Drugim rečima, na osnovu dobijenog ranga FKPO-a određuje se prioritet menadžment inicijativa koji treba da dovede do povećanja kapaciteta za oporavak MSP-a.

\section{Algoritam proširene FAHP}

Problem ocene i rangiranja FKPO-a u proizvodnim MSP, pomoću proširene FAHP, nadalje je prikazan.

Korak 1. Razmatrani problem je dekomponovan na nekoliko manje složenih upravljačkih problema. U ovom slučaju, konstruisane su fazi matrice parova upoređenja relativnog odnosa važnosti poslovnih procesa, $\tilde{W}_{p}^{e}=\left[\tilde{W}_{p p^{\prime}}^{e}\right]_{P X P}, p=1, . ., p ; e=1, \ldots, E$ i matrice pa- rova upoređenja relativne preferentnosti FKPO-a unutar svakog identifikovanog poslovnog procesa, $\tilde{W}_{i}^{p e}=\left[\tilde{W}_{i i}^{p e}\right]_{I X I}, i=1, . ., I ; p=1, \ldots, p ; e=1, \ldots, E$.

Korak 2. Izračunajmo vrednosti elemenata konstruisanih fazi matrica parova upoređenja na nivou jedne grupe MSP-a:

$$
\begin{aligned}
& \tilde{W}_{p p^{\prime}}^{g}=\frac{1}{E_{g}} \cdot \sum_{e=1}^{E_{g}} \tilde{W}_{p p^{\prime}}^{e}, \tilde{W}_{i i^{\prime}}^{p g}=\frac{1}{E_{g}} \cdot \sum_{e=1}^{E_{g}} \tilde{W}_{i i^{\prime}}^{p e}, \\
& p=1, . ., P ; i=1, . ., I ; e=1, . ., E_{g}
\end{aligned}
$$

gde je $E_{g}, g=1, \ldots, G$ ukupan broj menadžment timova MSP-a koji pripadaju grupi $g$.

Korak 3. Odredimo relativne važnosti identifikovanih poslovnih procesa i relativne važnosti FKPO-a unutar svakog poslovnog procesa na nivou svih razmatranih proizvodnih MSP-a primenom FOWA operatora:

$$
\begin{aligned}
& \tilde{w}_{p p^{\prime}}=\operatorname{FOWA}\left(\tilde{W}_{p p^{\prime}}^{g}\right)=\sum_{g=1}^{3} w_{g} \cdot \tilde{W}_{p p^{\prime}}^{g}, \\
& \tilde{w}_{i i^{\prime}}^{p}=\operatorname{FOWA}\left(\tilde{W}_{i i^{\prime}}^{p g}\right)=\sum_{g=1}^{3} w_{g} \cdot \tilde{W}_{i i^{\prime}}^{p g}, \\
& p=1, . ., P ; i=1, . ., I ; g=1,2,3
\end{aligned}
$$

Korak 4. Konstruišimo matrice relativnog odnosa važnosti identifikovanih poslovnih procesa,

$W_{p}=\left[w_{p p^{\prime}}\right]_{P X P}, p=1, \ldots, P$

i matrice relativnog odnosa preferentnosti FKPO-a unutar svakog poslovnog procesa,

$$
\begin{aligned}
& W_{i}^{p}=\left[w_{i i^{\prime}}^{p}\right]_{I x I}, p=1, . ., P ; i=1, . ., I \text { tako da: } \\
& \tilde{w}_{p p^{\prime}}=\operatorname{defuzz}\left(\tilde{w}_{p p^{\prime}}\right), w_{i i^{\prime}}^{p}=\operatorname{defuzz}\left(\tilde{w}_{i i^{\prime}}^{p}\right), \\
& i=1, . ., I ; p=1, . ., P
\end{aligned}
$$

$\mathrm{U}$ ovom radu korišćena je metoda momenta za dobijanje reprezentativnih skalara trougaonih fazi brojeva (Klir \& Folger, 1988).

Korak 5. Proverimo konzistentnost matrica $W_{p}=\left[w_{p p^{\prime}}\right]_{P X P}$ i $W_{i}^{p}=\left[w_{i i^{\prime}}^{p}\right]_{I X I}, p=1, . ., P ; i=1, . ., I$ Potreban uslov je da su elementi ovih matrica recipročni u odnosu na glavnu dijagonalu, a dovoljan 
uslov je da je sopstveni vektor svake matrice, $\lambda_{\max }$ jedanak dimenziji matrice (Saaty, 1990). Sopstveni vektor je prirodna mera nekonzistentnosti. Indeks nekonzistentnosti matrica $W_{p}$ i $W_{i}{ }^{p}, p=1, . ., P ; i=1, . ., I$ se računa:

C.I. $=$ C.R./R.I.

gde je:

$C . R .=\frac{\lambda_{\max }^{p}-P}{P-1}, C . R .=\frac{\lambda_{\max }^{i p}-I}{I-1}$

i sopstveni vektori matrica $W_{p}$ i $W_{i}{ }^{p}, p=1, . ., P ; i=1, . ., I$ su označeni kao $\lambda_{\text {max }}^{p}$ odnosno $\lambda_{\max }^{i p}$, respektivno.

Sopstvene vrednosti vektora dobijaju se iz matričnih jednačina:

$W_{p}^{\text {nor }} \cdot \lambda_{\text {max }}^{p}=\lambda_{\text {max }}^{p} \cdot\left(w_{p}\right)^{\prime},\left(W_{i}^{p}\right)^{\text {nor }} \cdot \lambda_{\text {max }}^{p}=$

$=\lambda_{\text {max }}^{i p} \cdot\left(w_{i p}\right)^{\prime}$

Elementi matrica $W_{p}^{\text {nor }} i\left(W_{i}{ }^{p}\right)^{\text {nor }}, i=1, . ., I ; p=1, . ., P$ su dobijeni primenom postupka linearne normalizacije za benefitan tip promenljivih (Hwang \& Yoon, 1981).

Indeks slučajne konzistentnosti, R.I. za svaku dimenziju matrice je dat u Tabeli 1 (Vargas, 1982).

Smatra se da je matrica konzistentna ako je C.I. manje od $10 \%$. U suprotnom, donosioci odluka moraju ponovo proceniti relativan odnos važnosti poslovnih procesa i/ili relativnu preferentnost FKPO-a unutar jednog ili svih identifikovanih poslovnih procesa. Eliminisanje nekonzistentnosti može da se postigne primenom metode koja je prikazana u radu (Harkar, 1987).

Korak 6. Odredimo vektor težina identifikovanih poslovnih procesa, $V_{p}=\left[w_{p}\right]_{1 \times P}, p=1, . ., P$ i vektor preferentnosti FKPO-a unutar svakog poslovnog procesa, $V_{i p}=\left[w_{i p}\right]_{1 \times I} ; i=1, \ldots, I ; p=1, . ., P$ primenom koncepta proširene analize (Chang, 1996).
Razmatrajmo skup objekata $X=\left\{x_{1}, \ldots, x_{i}, \ldots, x_{P}\right\}$ i skup ciljeva $Y=\left\{y_{1}, \ldots, y_{j}, \ldots, y_{P}\right\}$. Prema konceptu proširene analize (Chang, 1996), svakom objektu je pridružen po jedan cilj. Prema tome, dobijaju se P vrednosti primenom koncepta proširene analize, koje su označene na sledeći način $N_{i}^{1},, N_{i}^{j}, \ldots, N_{i}^{P}, i=1, . ., P$, gde su $N_{i}^{j}, j=1, . ., P$ trougaoni fazi brojevi.

Vrednosti fazi sintetičkih mera sa respektovanjem i-tog objekta, definisana je kao:

$\tilde{S}_{i}=\sum_{j=1}^{P} N_{i}^{j} \cdot\left[\sum_{i=1}^{P} \sum_{j=1}^{P} N_{i}^{j}\right]^{-1}$

gde:

$\sum_{j=1}^{P} N_{i}^{j}=\left(\sum_{p^{\prime}=1}^{P} l_{p p^{\prime}}, \sum_{p^{\prime}=1}^{P} m_{p p^{\prime}}, \sum_{p^{\prime}=1}^{P} u_{p p^{\prime}}\right)$

$\sum_{i=1}^{P} \sum_{j=1}^{P} N_{i}^{j}=\left(\sum_{p=1}^{P} \sum_{p^{\prime}=1}^{P} l_{p p^{\prime}}, \sum_{p=1}^{P} \sum_{p^{\prime}=1}^{P} m_{p p^{\prime}}, \sum_{p=1}^{P} \sum_{p^{\prime}=1}^{P} u_{p p^{\prime}}\right)$

Vektor težina identifikovanih poslovnih procesa je:

$\left(\left(\operatorname{Bel}\left(\tilde{S}_{1}\right)\right), \ldots,\left(\operatorname{Bel}\left(\tilde{S}_{i}\right)\right), \ldots,\left(\operatorname{Bel}\left(\tilde{S}_{P}\right)\right)\right)$

gde $\operatorname{Bel}\left(\tilde{S}_{i}\right)$ je mera verovanja da je trougaoni fazi broj $\tilde{S}_{i}$ veći ili jednak od svih ostalih trougaonih fazi brojeva $\tilde{S}_{i}^{\prime}, \quad\left(i, i^{\prime}=1, \ldots, P ; i \neq i^{\prime}\right)$. Ova vrednost je dobijena primenom metode za poređenje fazi brojeva (Dubois \& Prade, 1980; Bass \& Kwakernaak, 1977) (o poređenju fazi brojeva, videti u: Dodatku).

Posle normalizacije, dobija se vektor normalizovanih težina identifikovanih poslovnih procesa $V_{p}$ :

$V_{p}=\left(w_{1}, \ldots, w_{p}, \ldots, w_{P}\right)$

Tabela 1 Indeks slučajne konzistentnosti (R.I.)

\begin{tabular}{lcccccccccccc}
\hline Dimenzija matrice & 3 & 4 & 5 & 6 & 7 & 8 & 9 & 10 & 11 & 12 & 13 & 14 \\
R.I. & 0.58 & 0.90 & 1.12 & 1.24 & 1.32 & 1.41 & 1.45 & 1.49 & 1.51 & 1.48 & 1.56 & 1.57 \\
\hline
\end{tabular}

Izvor: Vargas, 1982. 
$w_{p}$ je precizan broj i predstavlja težinu jednog poslovnog procesa $u$ odnosu na sve ostale identifikovane poslovne procese.

Na sličan način dobijaju se vektori preferentnosti FKPO -a unutar svakog poslovnog procesa.

Korak 7. Izračunajmo indeks kombinovanog prioriteta za svaki FKPO, $r_{i}, i=1, \ldots, I$ :

$$
r_{i}=\sum_{p=1}^{P} w_{p} \cdot w_{i}^{p}, i=1, . ., I ; p=1, . ., P .
$$

Korak 8. Sortirajmo vrednosti indeksa kombinovanog prioriteta u monotono neopadajući red. Rang FKPO-a korespondira rangu indeksa kombinovanog prioriteta.

\section{ILUSTRATIVNI PRIMER}

Unapređenje kapaciteta za oporavak predstavlja veoma važno pitanje za menadžment timove procesnih MSP-a u zemljama u razvoju. Predložena metoda je ilustrovana realnim podacima dobijenim u 53 procesna MSP koja egzistiraju u Centralnoj Srbiji. Razmatrana MSP-a su sertifikovana prema zahtevima standarda ISO 9001, što je neophodno za definisanje referentnog modela organizacije. Kako se rangiranje faktora kapaciteta za oporavak vrši na nivou poslovnih procesa, važno je definisati iste u posmatranoj grupi preduzeća (Oakland, 2004). Identifikovani procesi $\mathrm{u}$ MSP procesne industrije mogu se podeliti na: menadžment $(\mathrm{p}=1)$, marketing i prodaju $(p=2)$, projektovanje i razvoj $(p=3)$, nabavku $(\mathrm{p}=4)$, proizvodnju $(\mathrm{p}=5)$, i procese podrške $(\mathrm{p}=6)$.

Faktori kapaciteta za oporavak MSP procesne industrije su prikazani u (Aleksic et al, 2013). Navedeni faktori kapaciteta za oporavak uključuju:

- planiranje strategije - faktor čiji je uticaj dominantan u procesima menadžmenta i aktivnostima strategije;

- sposobnosti i kapacitet internih resursa - faktor koji je ograničen na interne procese;

- interno praćenje situacije i izveštavanje - faktor koji je integrisan u interne procese;

- ljudski faktor - faktor čiji je uticaj dominantan u pogledu ljudskih resursa;
- kvalitet - faktor koji je integrisan u sve poslovne procese;

- eksterno praćenje situacije i izveštavanje - faktor koji je integrisan u eksterne procese;

- sposobnosti i kapacitet eksternih resursa - faktor koji je ograničen na eksterne procese;

- faktor projektovanja - faktor koji je integrisan u proizvodne operacije;

- potencijal za detekciju otkaza - faktor čiji je uticaj dominantan u procesima osetljivim na devijacije od željenih ciljeva;

- odgovor u vanrednom stanju - faktor čiji je uticaj dominantan u periodu krize;

- sistem menadžmenta bezbednošću - faktor koji je integrisan u aktivnosti vezane za bezbednost zaposlenih i imovine preduzeća.

Sva razmatrana MSP-a su sortirana prema godišnjem prihodu u monotono opadajući red. Respektujući pravila $A B C$ klasifikacije, grupa A sastoji se od 5 MSP-a, u grupi B se nalaze 19 MSP-a, a svih ostalih 29 MSP-a pripada grupi C. Važnost ovih grupa je $w_{A}=0.45, w_{B}=0.35, w_{C}=0.2$. Važnost grupa je određena na osnovu procene eksperata koji su proučavali jačinu uticaja preduzeća na realizaciju strategije razvoja države.

Primenjujući razvijeni algoritam (Korak 1 do Koraka 3) dobijaju se vrednosti svakog elementa konstruisanih fazi matrica parova upoređenja. Nadalje je razvijeni postupak ilustrovan na primeru određivanja relativnog odnosa važnosti poslovnih procesa menadžmenta $(\mathrm{p}=1)$ i marketinga i prodaje $(\mathrm{p}=2)$.

Menadžment timovi MSP-a grupe A, relativan odnos važnosti ova dva procesa procenili su na sledeći način: srednja važnost, velika važnost $\mathrm{x} 3 \mathrm{i}$ veoma velika važnost. Menadžment timovi grupe $B$, procenu su izvršili na sledeći način: mala važnost $x 2$, srednja važnost $x 4$, velika važnost $x 10$ i veoma velika važnost $x 4$. Procena menadžment timova grupe $C$ je: srednja važnost $x 11$, velika važnost $x 11$ i veoma velika važnost $\times 5$.

Relativna važnost ova dva razmatrana poslovna procesa na nivou svake grupe je: 


$$
\begin{aligned}
& \tilde{W}_{12}^{A}=\frac{1}{5} \cdot\left(\tilde{R}_{3}+3 \cdot \tilde{R}_{4}+\tilde{R}_{5}\right)=(2.8,4,5), \\
& \tilde{W}_{12}^{B}=\frac{1}{19} \cdot\left(\tilde{R}_{2}+4 \cdot \tilde{R}_{3}+10 \cdot \tilde{R}_{4}+4 \cdot \tilde{R}_{5}\right)= \\
& =(2.68,3.89,4.89) \\
& \tilde{W}_{12}^{C}=\frac{1}{29} \cdot\left(11 \cdot \tilde{R}_{3}+11 \cdot \tilde{R}_{4}+5 \cdot \tilde{R}_{5}\right)=(2.21,3.52,5) .
\end{aligned}
$$

Relativna važnost poslovnih procesa menadžmenta $(p=1)$ i marketinga i prodaje $(p=2)$ na nivou 53 razmatrana proizvodna preduzeća se računa kao:

$\tilde{w}_{12}=0.45 \cdot \tilde{W}_{12}^{A}+0.35 \cdot \tilde{W}_{12}^{B}+0.2 \cdot \tilde{W}_{12}^{C}=(2.28,3.87,5)$.

$\mathrm{Na}$ isti način se računaju fazi vrednosti elemenata svih konstruisanih fazi matrica parova upoređenja.

Procedure koje su definisane $\mathrm{u}$ razvijenom algoritmu (Korak 4 do Koraka 6), ilustrovane su na primeru provere konzistentnosti matrice parova upoređenja relativnog odnosa važnosti identifikovanih poslovnih procesa.

Primenom algoritma (Korak 4) dobija se matrica parova upoređenja relativnog odnosa važnosti poslovnih procesa, čiji elementi su precizni brojevi:

$$
W_{p}=\left[\begin{array}{cccccc}
1 & 3.87 & 4.39 & 3.82 & 1.97 & 2.28 \\
0.53 & 1 & 1.35 & 0.98 & 0.44 & 0.99 \\
0.23 & 0.74 & 1 & 0.58 & 0.39 & 0.43 \\
0.26 & 1.02 & 1.72 & 1 & 0.64 & 1.89 \\
0.51 & 2.27 & 2.56 & 1.57 & 1 & 3.97 \\
0.44 & 1.01 & 2.33 & 0.53 & 0.25 & 1
\end{array}\right] .
$$

Proverimo konzistentnost ove matrice (Korak 5 razvijenog algoritma).

$$
W_{p}^{\text {nor }}=\left[\begin{array}{llllll}
0.337 & 0.391 & 0.329 & 0.450 & 0.420 & 0.215 \\
0.178 & 0.101 & 0.101 & 0.116 & 0.094 & 0.094 \\
0.077 & 0.075 & 0.075 & 0.068 & 0.083 & 0.041 \\
0.088 & 0.103 & 0.129 & 0.118 & 0.136 & 0.179 \\
0.172 & 0.229 & 0.192 & 0.185 & 0.213 & 0.376 \\
0.148 & 0.102 & 0.175 & 0.062 & 0.053 & 0.095
\end{array}\right]
$$

$$
\left(w_{p}\right)^{\prime}=\left[\begin{array}{l}
0.357 \\
0.114 \\
0.070 \\
0.125 \\
0.259 \\
0.106
\end{array}\right]
$$

Primenjujući razvijeni postupak za proveru konzistentnosti (Harker, 1987), dobija se da je vektor težina identifikovanih poslovnih procesa $\mathrm{u}$ prvoj iteraciji:

$w_{p}^{1}=\frac{A \cdot e}{e^{T} \cdot A \cdot e}=$

$=\left[\begin{array}{llllll}0.347 & 0.106 & 0.067 & 0.131 & 0.238 & 0.111\end{array}\right]^{T}$.

Očigleno je da konzistentnost nije postignuta u prvoj iteraciji. Nastavljajući ovaj proces, vektor težina poslovnih procesa dobija se $u$ petoj iteraciji:

$w_{p}=\left[\begin{array}{llllll}0.361 & 0.098 & 0.071 & 0.129 & 0.236 & 0.105\end{array}\right]^{T}$

Provera konzistentnosti matrica preferentnosti FKPO-a unutar svakog poslovnog procesa je izvršena prema postupku koji je opisan u Koraku 4 predloženog algoritma.

Izračunate vrednosti dobijene primenom algoritma (Korak 1 do Korak 6) prikazane su u Tabeli 2.

Primenjujući predloženi algoritam (Korak 7 i Korak 8) izračunate su vrednosti indeksa kombinovanog prioriteta.

$\mathrm{Na}$ osnovu izračunatih vrednosti indeksa kombinovanog prioriteta, može se zaključiti da FKPO-a koji imaju najviše uticaja na kapacitet za oporavak procesnih MSP-a su planiranje strategije $(i=1)$ i kvalitet $(i=5)$. Dobijeni rezultat pokazuje da je neophodno da se prvo preduzmu menadžment inicijative koje treba da dovedu do povećanja ova dva FKPO-a, na primer: kontinualno unapređenje procesa, unapređenje komunkacije između svih zaposlenih u preduzeću, kao i unapređenje komunikacije menadžment timova i stakeholder-a. Efektivnost menadžment mera je veća ako 
Tabela 2 Težine identifikovanih poslovnih procesa i preferentnost FKPO unutar svakog poslovnog procesa

\begin{tabular}{|c|c|c|c|c|c|c|}
\hline & $p=1$ & $p=2$ & $p=3$ & $p=4$ & $p=5$ & $\mathrm{p}=6$ \\
\hline $\mathrm{i}=1$ & 0.011 & 0.036 & 0.027 & 0.04 & 0.059 & 0.06 \\
\hline $\mathrm{i}=2$ & 0.033 & 0.045 & 0.039 & 0.102 & 0.053 & 0.072 \\
\hline$i=3$ & 0.074 & 0.088 & 0.036 & 0.071 & 0.066 & 0.074 \\
\hline$i=4$ & 0.077 & 0.074 & 0.088 & 0.072 & 0.074 & 0.091 \\
\hline$i=5$ & 0.173 & 0.129 & 0.150 & 0.104 & 0.121 & 0.167 \\
\hline$i=6$ & 0.041 & 0.092 & 0.155 & 0.059 & 0.041 & 0.056 \\
\hline $\mathrm{i}=7$ & 0.126 & 0.114 & 0.091 & 0.104 & 0.117 & 0.096 \\
\hline$i=8$ & 0.083 & 0.075 & 0.055 & 0.090 & 0.112 & 0.09 \\
\hline$i=9$ & 0.185 & 0.189 & 0.230 & 0.209 & 0.141 & 0.122 \\
\hline $\mathrm{i}=10$ & 0.039 & 0.050 & 0.023 & 0.047 & 0.095 & 0.065 \\
\hline $\mathrm{i}=11$ & 0.157 & 0.105 & 0.106 & 0.102 & 0.120 & 0.108 \\
\hline $\begin{array}{l}\text { Težine poslovnih } \\
\text { procesa }\end{array}$ & 0.361 & 0.098 & 0.071 & 0.129 & 0.236 & 0.105 \\
\hline
\end{tabular}

Izvor: Autori

se u preduzeću koriste informaciono-komunikacione tehnologije (ICT). S druge strane, FKPO koji je označen kao potencijal detekcije (i=9), ima najmanji uticaj na kapacitet za opravak preduzeća, što je realno, s obzirom na činjenicu da se razmatraju MSP-a u

Tabela 3 Vrednosti indeksa kombinovanog prioriteta i rang FKPO-a

\begin{tabular}{lcc}
\hline & $r_{i}$ & Rang \\
\cline { 2 - 3 } $\mathrm{i}=1$ & 0.1480 & 1 \\
$\mathrm{i}=2$ & 0.0533 & 10 \\
$\mathrm{i}=3$ & 0.070 & 7 \\
$\mathrm{i}=4$ & 0.078 & 6 \\
$\mathrm{i}=5$ & 0.146 & 2 \\
$\mathrm{i}=6$ & 0.058 & 8 \\
$\mathrm{i}=7$ & 0.114 & 4 \\
$\mathrm{i}=8$ & 0.089 & 5 \\
$\mathrm{i}=9$ & 0.0348 & 11 \\
$\mathrm{i}=10$ & 0.056 & 9 \\
$\mathrm{i}=11$ & 0.127 & 3 \\
\hline
\end{tabular}

Izvor: Autori kojima sistem kvaliteta ne sadrži veliki broj procedura s obzirom na veličinu preduzeća.

\section{ZAKLJUČAK}

Promene koje nastaju $\mathrm{u}$ neizvesnom poslovnom okruženju zahtevaju razvoj i primenu novih menadžment koncepata čiji je zadatak da dovedu do povećanja efektivnosti poslovanja i postizanja održivosti preduzeća tokom vremena.

Prva hipoteza je potvrđena na osnovu zahteva standarda ASIS SPC.1-2009 koji je kompatibilan sa serijom standarda ISO 9001, ISO 14001 i ISO 27001. Broj FKPO-a kojima se meri kapacitet za opravak preduzeća je definisan u odnosu na vrstu preduzeća koja se razmatra u ovom radu (Aleksić et al, 2013).

Modeliranje relativnih važnosti poslovnih procesa i relativnih preferentnosti FKPO-a je zasnovano na korišćenju fazi skupova. Fazi pristup je lako razumljiv, fleksibilan je i tolerantan na neprecizne podatke.

Ocenjivanje i rangiranje FKPO-a predstavljaju jedan od najvažnijih problema upravljanja kapacitetom 
za oporavak organizacija u svim preduzećima koja posluju u promenljivom i neizvesnom okruženju. Prema mišljenju autora, predložena fazi AHP je odgovarajuća metoda za određivanje ranga FKPO-a na egzaktan način. Dobijeni prioritet je manje opterećen subjektivnim stavovima donosilaca odluka i ostalih stakeholder-a, pa se može smatrati da će efektivnost strategije poboljšanja biti veća, što je jedan od osnovnih ciljeva menadžment tima bilo kog preduzeća u kojem se obavljaju različite privredne delatnosti.

Doprinosi ovog modela mogu da se iskažu na sledeći način: (1) identifikovanje poslovnih procesa i FKPO-a za procesna mala i srednja preduzeća; (2) obrada neizvesnosti u relativnim odnosima važnosti poslovnih procesa i relativnim prioriterima FKPO je izvršena pomoću teorije fazi skupova; (3) agregiranje procena menadžment timova u grupni konsenzus je dobijeno primenom operatora fazi otežane srednje vrednosti; (4) rang selektovanih FKPO-a je korespondentan vrednostima indeksa kombinovanog prioriteta; (5) rang FKPO-a dopušta preduzećima da uče tokom vremena čime se povećava efektivnost poslovnih procesa i kontinualni razvoj.

Pored pomenutih prednosti, predloženi model ima izvesna ograničenja. Može da se proširi u smislu boljeg strukturiranja poslovnih procesa, povećanja broja FKPO-a u zavisnosti od veličine preduzeća i/ ili vrste privredne delatnosti koja se realizuje $u$ preduzećima. Sva ova proširenja mogu lako i brzo da se inkorporiraju u predloženi model i ne povećavaju složenost matematičkog računanja.

Predloženi model je testiran na grupi malih i srednjih preduzeća procesne industrije koja funkcionišu u Centralnoj Srbiji.

Kontinualno unapređenje poslovnih procesa (što predstavlja jedan od osnovnih zahteva ISO 9000:2008) postiže se razvojem i primenom adekvatnih strategija poboljšanja za svaku grupu identifikovanih indikatora, pomoću kojih se meri efektivnost poslovnih procesa. Rezultati dobre prakse pokazuju da primena menadžment inicijativa, koje su zasnovane na prioritetu indikatora, omogućavaju da se unapređenje poslovnih procesa realizuje $\mathrm{u}$ kraćem vremenskom periodu i da troškovi unapređenja budu značajno niži. Prioritet indikatora, na primer, FKPO, može se odredi na egzaktan način primenom postupka, predloženog $\mathrm{u}$ ovom radu.

Buduća istraživanja biće usmerena na razvoj i/ ili modifikaciju pristupa koji mogu da se nađu u referentnoj literaturi, za obradu fazi matrica neizvesnosti koje egzistiraju u razmatranom problemu. Primenom novih pristupa dobija se fazi rang FKPO na osnovu kojeg menadžment timovi mogu da izvrše kvalitetniju analizu njihovog prioriteta. Identifikovanje FKPO i određivanje njihovog prioriteta $u$ javnim preduzećima i preduzećima uslužnih delatnosti su, takođe, pravci daljih istraživanja. Razvoj računarskog programa koji je zasnovan na modelu, prema mšljenju autora, može da omogući brzu i kvalitetnu analizu prioriteta FKPO u različitim preduzećima.

\section{ZAHVALNICA}

Ovaj rad predstavlja deo istraživačkog Projekta (br. 44010), koji finansira Ministarstvo nauke Republike Srbije.

\section{REFERENCE}

Adger, W. N. (2000). Social and ecological resilience: are they related? Progress in Human Geography, 24(3), 347-364.

Afgan, N. H., Hovanov, N., \& Andre, P. M. (2009). Sustainable management organization with example of passenger car sustainability assessment. International Journal for Quality Research, 3(2), 159-169.

Aleksić, A., Stefanović, D., Arsovski, S., \& Tadić, D. (2013). (In press). An assessment of organizational resilience potential in SMEs of the process industry: A fuzzy approach. Journal of Loss Prevention in the Process Industries, doi: 10.1016/j. jlp.2013.06.004.

Bass, M. S., \& Kwakernaak, H. (1977). Rating and ranking of multiple-aspect alternatives using fuzzy sets. Automatica, 3, $47-58$.

Bortolan, G., \& Degani, R. (1985). A review of some methods for ranking fuzzy subsets. Fuzzy Sets and Systems, 29, 145-153. 
Bozbura, T. F., \& Beskese, A. (2007). Prioritization of organizational capital measurement indicators using fuzzy AHP. International Journal of Approximate Reasoning, 44(2), 124-147.

Carvalho, P., dos Santos, I., Gomes, J., \& Borges, M. (2008). Micro incident analysis framework to assess safety and resilience in the operation of safe critical systems: A case study in a nuclear power plant. Journal of Loss Prevention in the Process Industries, 21, 277-286.

Chan, J. (2011). Enhancing organisational resilience: application of viable system model and MCDA in a small Hong Kong company. International Journal of Production Research, 49(18), $5545-5563$.

Chang, D. Y. (1996). Applications of the extent analysis method on fuzzy AHP. European Journal of Operational Research, 95, 649-655.

Dinh, L., Pasman, H., Gao, X., \& Mannan, M. S. (2012). Resilience engineering of industrial processes: Principles and contributing factors. Journal of Loss Prevention in the Process Industries, 25, 233-241.

Dubois, D., \& Prade, H. (1980). Fuzzy Sets and Systems: Theory and Applications. London, UK: Academic press, INC (LONDON) LTD.

Folke, C. (2006). Resilience: The emergence of a perspective for, social-ecological systems analyses. Global Environmental Change, 16, 253-267.

Harkar, P. T. (1987). Derivatives of the Perron root of a positive reciprocal matrix: with application to the Analytic Hierarchy Process. Applied Mathematics and Computation, 22, 217-232.

Hollnagel, E., Woods, D. D., \& Leveson, N. (2006). Resilience engineering: concepts and precepts. Aldershot, USA: Ashgate.

Hwang, C. L., \& Yoon, K. (1981). Multiple Attribute Decision Making-Methods and Applications. Heidelberg, Germany: Springer Verlag.

Klir, G. J., \& Folger, T. A. (1988). Fuzzy Sets, Uncertainty and Informations. New Jersy, USA: Prentice-Hall, Englewood Cliffs.

Klir, G. J., \& Yuan, B. (1995). Fuzzy Sets and Fuzzy Logic, Theory and Applications. New Jersy, USA: Prentice Hall.

Kong, F., \& Liu, H. (2005). Applying fuzzy Analytic Hierarchy Process to evaluate success factors of e-commerce. International Journal of Information and Systems Sciences, 183(4), 406-412.
Kwong, C. K., \& Bai, H. (2003). Determining the importance weights for the customer requirements in QFD using a fuzzy AHP with an extent analysis approach. IIE Transaction, 35(7), 619-626.

Lee, Y., Shin, J., \& Park, Y. (2012). The changing pattern of SME's innovativeness through business model globalization. Technological Forecasting \& Social Change, 79, 832-842.

Lengnick-Hall, C. A., Beck, T. E., \& Lengnick-Hall, M. L. (2011). Developing a capacity for organizational resilience through strategic human resource management. Human Resource Management Rewiev, 21, 243-255.

Merigó, J. M., \& Casonovas, M. (2008). Using fuzzy numbers in heavy aggregation operators. International Journal of Information Technology, 4, 177-182.

Oakland, J. (2004). Oakland on Quality Management. Boston, USA: Elsevier Butterworth - Heinemann.

Pendall, R., Foster, K., \& Cowell, M. (2010). Resilience and regions: building understanding of the metaphor. Cambridge Journal of Regions, Economy and Society, 3, 71-84.

Saaty, T. L. (1990). How to make a decision: The Analytic Hierarchy Process. European Journal of Operational Resarch, $48,9-26$

Spekman, R., \& Davis, E. (2004). Risky business: expanding the discussion on risk and the extended enterprise. International Journal of Physical Distribution and Logistics Management, 34(5), 414-433.

Tadić, D., Gumus, T. A., Arsovski, S., Aleksić, A., \& Stefanović, M. (2013). An evaluation of quality goals by using fuzzy AHP and fuzzy TOPSIS methodology. Journal of Intelligent $\mathcal{E}$ Fuzzy Systems, 25, 547-556. doi:10.3233/IFS-120659.

Torfi, F. R. Z., Farahani, R. Z., \& Rezapour, S. (2010). Fuzzy AHP to determine the relative weights of evaluation criteria and fuzzy TOPSIS to rank the alternatives. Applied Soft Computing, 10, 520-528.

Vargas, L. G. (1982). Reciprocal matrices with random coefficients. Mathematical Modelling, 3, 69-81.

Vidal, M., Carvalho, P., Santos, M., \& dos Santos, I. (2009). Collective work and resilience of complex systems. Journal of Loss Prevention in the Process Industries, 22, 516-527.

Vossen, R. W. (1998). Relative strengths and weaknesses of small firms in innovation. International Small Business Journal, 16, 88-94.

Weeck M., Klocke, F., Schell, H., \& Ruenauver, E. (1997). Evaluating alternative production cycles using the extended fuzzy AHP method. European Journal of Operational Research, 100(2) 351-365. 
Wymenga, P., Spanikova, V., Barker, A., Konings, J., \& Canton, A. (2012). EU SMEs in 2012: at the crossroads Annual report on small and medium-sized enterprises in the EU, 2011/12, Ecorys, Rotterdam.

Xi, X., \& Qin, Q. (2013). Product quality evaluation system based on AHP fuzzy comprehensive evaluation. Journal of Industrial Engineering and Management, 6(1), 356-366.
Zadeh, L. A. (1975). The concept of a linguistic variable and its application to approximate reasoning. Information Sciences, 8(3), 199-249.

Zimmermann, H. J. (2001). Fuzzy Set Theory and its Applications. Boston, USA: Kluwer Nijhoff Publishing.

Danijela Tadić je redovni profesor na Fakultetu inženjerskih nauka Univerziteta u Kragujevcu, na nastavnim predmetima: Organizacija proizvodnje i operaciona istraživanja, Metode veštačke inteligencije u menadžmentu i Organizacija rada. Doktorirala je na Mašinskom fakultetu Univerziteta u Beogradu. Autor je i koautor deset nastavnih udžbenika i naučnih monografija, 14 radova publikovanih $\mathrm{u}$ časopisima sa SCI liste i brojnih radova prezentiranih na međunarodnim $\mathrm{i}$ nacionalnim konferencijama.

Aleksandar Aleksić je istraživač saradnik u Centru za kvalitet na Fakultetu inženjerskih nauka Univerziteta u Kragujevcu, gde je i doktorirao. Izvodi nastavu na nastavnim predmetima: Osnovi preduzetničkog menadžmenta i ekonomija, Menadžment procesima, Menadžment kvalitetom i Menadžment komunikacijama. Koautor je jedne naučne monografije, 5 radova publikovanih u časopisima sa SCI liste i više radova izloženih na međunarodnim i nacionalnim konferencijama. 


\section{DODATAK: POREĐENJE FAZI BROJEVA}

U ovom Dodatku prikazan je jednostavan metod za poređenje kontinualnih fazi brojeva (Bass \& Kwakernaak, 1977, Dubois \& Prade, 1980).

Neka su data dva fazi broja $\tilde{A}$ i $\tilde{B}$ koja su definisana na skupu realnih brojeva R:

$\tilde{A}=\left(x ; l_{1}, m_{1}, u_{1}\right)$ i $\tilde{B}=\left(y ; l_{2}, m_{2}, u_{2}\right)$

Gde $l_{1}, l_{2}, u_{1}, u_{2}$ su donje odnosno gornje granice i $m_{1}, m_{2}$ su modalne vrednosti ova dva fazi broja $\tilde{A} \mathrm{i}$ $\tilde{B}$, respektivno. Neka je $m_{2}<m_{1}$ i $l_{2}<l_{1}<u_{2}$ i $l_{1}<u_{2}<u_{1}$.

Stepen verovanja da je fazi broj $\tilde{B}$ veći ili jednak od fazi broja $\tilde{A}$ je označen kao $\operatorname{Bel}(\tilde{B} \geq \tilde{A})$ koji je dobijen korišćenjem operacija max i min (Dubois \& Prade, 1980):

$\operatorname{Bel}(\tilde{B} \geq \tilde{A})=\sup _{x \geq y} \min \left(\mu_{\tilde{A}}(x), \mu_{\tilde{B}}(y)\right)$

Možemo da definišimo sledeće izraze:

1. Bel $(\tilde{A} \geq \tilde{B})=1$, ako je $\mu_{\tilde{A}}\left(m_{1}\right)=1$ i $\mu_{\tilde{B}}\left(m_{2}\right)=1$ i $m_{1}>m_{2}$

2. U isto vreme $\operatorname{Bel}(\tilde{B} \geq \tilde{A})$ je jednak ordinate tačke preseka fazi brojeva $\tilde{A}$ i $\tilde{B}$.

$\operatorname{Bel}(\tilde{B} \geq \tilde{A})$ ordinate tačke preseka.

Kada su $\tilde{A}$ i $\tilde{B}$ trougaoni fazi brojevi, tada ordinate tačke preseka se računa:

$$
\operatorname{Bel}(\tilde{B} \geq \tilde{A})=\frac{l_{1}-u_{2}}{\left(m_{2}-u_{2}\right)-\left(m_{1}-l_{1}\right)}
$$

Za određivanje vektora težina poslovnih procesa i vektora prioriteta FKPO-a potrebno je prikazati postupak računanja mere verovanja da je trougaoni fazi broj $\tilde{A}$ veći ili jednak od K trougaonih fazi brojeva $\tilde{B}_{1}, \ldots, \tilde{B}_{k}, \ldots, \tilde{B}_{K^{\prime}}$ (Bass \& Kwakernaak, 1977):

$$
\begin{aligned}
& \operatorname{Bel}\left(\tilde{A} \geq\left(\tilde{B}_{1}, \ldots, \tilde{B}_{k}, \ldots ., \tilde{B}_{K}\right)\right)= \\
& =\underset{\substack{t \geq t_{1} \\
\ldots . . \\
t \geq t_{k}}}{\quad \sup \min }\left(\mu_{\tilde{A}}(t), \mu_{\tilde{B}_{1}}\left(t_{1}\right), \ldots, \mu_{\tilde{B}_{k}}\left(t_{k}\right), \ldots, \mu_{\tilde{B}_{K}}\left(t_{K}\right)\right) \\
& \quad \operatorname{Bel}\left(\left(\tilde{A} \geq \tilde{B}_{K}\right), \text { and }\left(\tilde{A} \geq \tilde{B}_{2}\right), \ldots,\left(\tilde{A} \geq \tilde{B}_{k}\right), \ldots,\left(\tilde{A} \geq \tilde{B}_{K}\right)\right)= \\
& \min _{k=1, . . K} \operatorname{Bel}\left(\tilde{A} \geq \tilde{B}_{k}\right)
\end{aligned}
$$




\title{
RANKING ORGANIZATIONAL RESILIENCE FACTORS IN ENTERPRISES USING A MODIFIED FUZZY ANALYTICAL HIER ARCHY PROCESS
}

\author{
Danijela Tadic, Aleksandar Aleksic \\ Faculty of Engineering, University of Kragujevac, Kragujevac, Serbia
}

\begin{abstract}
In the last few decades, the concept of organizational resilience has been developed, and in that manner, it represents an adequate management method for enterprises operating in the conditions of the economic crisis. In this paper, the problem of organizational resilience factors prioritization (ORF) is considered, which represents the first step in the determining of improvement strategies. The ORF ranking is set up as a task of a multi-criterion optimization inclusive of qualitative variables. Management teams at the level of every company assess the relative importance of each pair of business processes and the preference of the ORF within each business process using predefined linguistic expressions. The modeling of linguistic expressions is based on the theory of fuzzy sets. The aggregated values of the considered variables are obtained by applying the fuzzy ordered weighted averaging operator. The vector of a combined ORF priority was determined by using the fuzzy Analytic Hierarchy Process. The proposed model is illustrated by an illustrative example where the used data is obtained from the process of small and medium enterprises (SMEs) operating in central Serbia. It is shown that the developed model is very suitable for making decisions on changing business strategies in order to increase organizational resilience.
\end{abstract}

Keywords: organizational resilience factors, fuzzy set, fuzzy ordered weighted averaging operator (FOWA), fuzzy Analytic Hierarchy Process (FAHP)

JEL Classification: C61, D80, O21 